\title{
History of Archeological Investigations at Palo Duro Canyon State Park
}

Veronica M. Arias

Panhandle-Plains Historical Museum, West Texas A\&M University

Anthony S. Lyle

Texas Parks and Wildlife Department

Rolla H. Shaller

Panhandle-Plains Historical Museum

Follow this and additional works at: https://scholarworks.sfasu.edu/ita

Part of the American Material Culture Commons, Archaeological Anthropology Commons, Environmental Studies Commons, Other American Studies Commons, Other Arts and Humanities Commons, Other History of Art, Architecture, and Archaeology Commons, and the United States History Commons

Tell us how this article helped you.

This Article is brought to you for free and open access by the Center for Regional Heritage Research at SFA ScholarWorks. It has been accepted for inclusion in Index of Texas Archaeology: Open Access Gray Literature from the Lone Star State by an authorized editor of SFA ScholarWorks. For more information, please contact cdsscholarworks@sfasu.edu. 


\section{History of Archeological Investigations at Palo Duro Canyon State Park}

\section{Licensing Statement}

Reproduction, posting, transmission, or other distribution or use of the Journal volume, individual article or any portion of the material therein, in any medium, is permitted strictly for personal, non-commercial purposes via a personal-use exemption under a Creative Commons license granted by JTAH.org, Inc. This license exemption requires, as a condition of its granted permission, proper credit be attributed to JTAH.org as copyright holder (e.g., Journal of Texas Archeology and History.org @ 2019). No part of this publication may be reproduced, posted, transmitted, or otherwise utilized or distributed in any form by any means or method for commercial purposes without the express written consent of the Publisher.

Inquiries should be addressed to JTAH Publisher, Suite 307, Box 361, 5114 Balcones Woods Drive, Austin, Texas, 78759.

The Journal of Texas Archeology and History.org is an organization dedicated to furthering research, education and public outreach in the fields of archeology and history concerning Texas and its bordering states of Louisiana, Arkansas, Oklahoma, New Mexico and Northern Mexico; a region we call the "Texas Borderlands." The J.T.A.H. is collaborating with the Index of Texas Archaeology and S.F.A.S.U. to distribute their publication library to the general public via free and open-access channels. Visit www.JTAH.org to submit an article. 


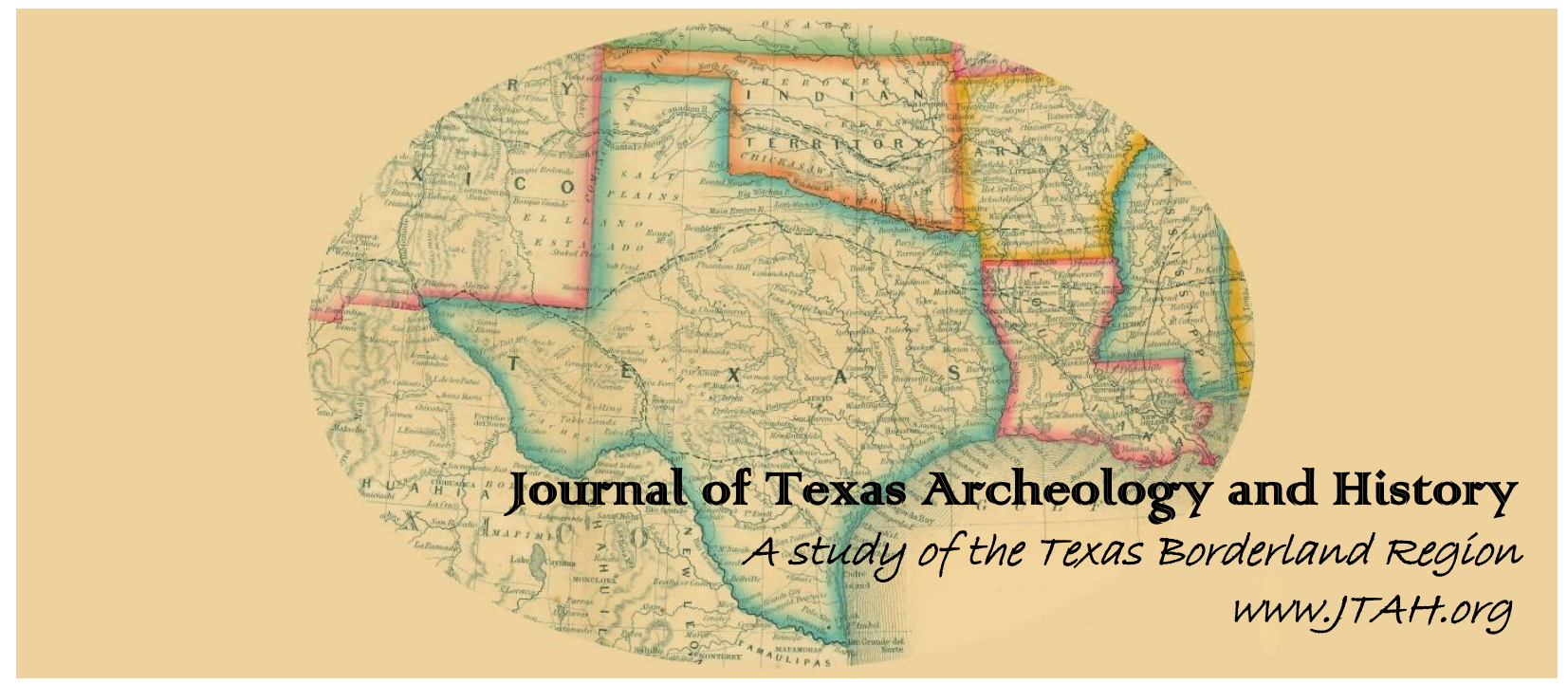

\title{
Article Title: HISTORY OF ARCHEOLOGICAL INVESTIGATIONS AT PALO DURO CANYON STATE PARK
}

\author{
Author(s): $\quad$ Veronica M. Arias, West Texas A\&M University \\ Anthony S. Lyle, Texas Parks and Wildlife Department \\ Rolla H. Shaller, Panhandle-Plains Historical Museum
}

Original Source: J.T.A.H. Volume 5 (2018/2019), Article 1, pp. 1 - 40; online 27 December 2019

Recommended Citation: Arias, Veronica M., Anthony S. Lyle and Rolla H. Shaller; "History of Archeological Investigations at Palo Duro Canyon State Park", (2019), Journal of Texas Archeology and History Volume 5 (2018/2019), pp. 1 - 40.

Copyright $(C 2019$ by Journal of Texas Archeology and History.org, Inc. All rights reserved. Online/Digital publication: ISSN 2334-1874

The online, digital, and print versions of the publication "Journal of Texas Archeology and History" are published by Journal of Texas Archeology and History.org, Inc., a Texas nonprofit IRC Section 501(c)(3) corporation.

Reproduction, posting, transmission, or other distribution or use of the Journal volume, individual article or any portion of the material therein, in any medium, is permitted strictly for personal, non-commercial purposes via a personal-use exemption under a Creative Commons license granted by JTAH.org, Inc. This license exemption requires, as a condition of its granted permission, proper credit be attributed to JTAH.org as copyright holder (e.g., Journal of Texas Archeology and History.org (c) 2019). No part of this publication may be reproduced, posted, transmitted, or otherwise utilized or distributed in any form by any means or method for commercial purposes without the express written consent of the Publisher. Inquiries should be addressed to JTAH Publisher, Suite 307, Box 361, 5114 Balcones Woods Drive, Austin, Texas, 78759.

The Journal of Texas Archeology and History.org is an organization dedicated to furthering research, education and public outreach in the fields of archeology and history concerning Texas and its bordering states of Louisiana, Arkansas, Oklahoma, New Mexico and Northern Mexico; a region we call the "Texas Borderlands." The J.T.A.H. is collaborating with the Index of Texas Archaeology and S.F.A.S.U. to distribute their publication library to the general public via free and open-access channels. Visit www.JTAH.org to submit an article. 


\title{
HISTORY OF ARCHEOLOGICAL INVESTIGATIONS AT PALO DURO CANYON STATE PARK
}

\author{
Veronica M. Arias, West Texas A\&M University \\ Anthony S. Lyle, Texas Parks and Wildlife Department \\ Rolla H. Shaller, Panhandle-Plains Historical Museum
}

\begin{abstract}
Palo Duro Canyon has been an important locale for human occupation with its distinct topography, fauna, and flora from the Paleoindian inhabitants to those of the Historic Period. There is archeological evidence of human habitation at Palo Duro Canyon throughout the past 12 millennia. Native Americans who lived in and around the canyon had access to resources not easily found on the adjoining upland plains. The canyon provided an abundance of sheltered camping and year-round supply to water, wood, stone tool materials, game, and wild plant resources. The bordering uplands, covered with grass and dotted with playa lakes, afforded campsites with good visibility and access to game such as bison, antelope, and waterfowl. This article reviews the history of archaeological work conducted at Palo Duro Canyon State Park since the park opened in 1934. It examines how evolving site recording standards, archaeological methods, and construction projects have influenced the types of archaeological investigations that have been conducted within the park over time. These investigations have occurred within the context of larger changes to the discipline and, more recently, expansions to the original park boundaries. Together, they help elucidate on the rich history of human occupation in the region.
\end{abstract}

\section{INTRODUCTION}

Palo Duro Canyon has been an important locale for human occupation for millennia. The unique topography, fauna, and flora that attracted the earliest inhabitants into the region continued to exert strong appeal for later Native American groups well into the Historic Period. From the broken Paleoindian spear points left behind by the earliest occupants, to the artifact assemblages that indicate the presence of successive Native American groups through the Archaic, Ceramic, and Protohistoric Periods, to the material remains discarded by the U.S. Cavalry, Hispanic sheepherders, and Anglo ranchers, to the Civilian Conservation Corps (CCC) architecture and modern park infrastructure, the story of human interaction with this singular landscape is everywhere within the confines of the modern day state park. There is archeological evidence of human habitation at Palo Duro Canyon throughout the past 12,000 years. Native Americans who lived in and around the canyon had access to resources not easily found on the adjoining upland plains. The canyon provided an abundance of sheltered camping and year-round supply to water, wood, stone tool materials, game, and wild plant resources. The bordering uplands, covered with

\footnotetext{
JOURNAL OF TEXAS ARCHEOLOGY AND HISTORY

VOLUME $5: 1-40$

THE ONLINE PUBLICATION JOURNAL OF TEXAS ARCHEOLOGY AND HISTORY (ISSN 2334-1874)

IS PUBLISHED BY JOURNAL OF TEXAS ARCHEOLOGY AND HISTORY.ORG, INC.

Copyright (c) 2019 Journal of Texas Archeology and History.org. All rights reserved.
} 
grass and dotted with playa lakes, afforded campsites with good visibility and access to game such as bison, antelope, and waterfowl.

This paper reviews the history of archeological research conducted at Palo Duro Canyon State Park (PDCSP) since the park opened to the public in 1934. It examines how evolving site recording standards, archeological methods, and construction projects have influenced the types of archeological investigations that have been conducted within the park over time. These investigations have occurred within the context of larger changes to the discipline and, more recently, expansions to the original park boundaries. Together, they help elucidate the rich history of human occupation in the region.

Since opening, PDCSP has almost doubled in acreage. During the intervening 85 years, Texas Parks and Wildlife Department (TPWD), the state agency that manages the park, has worked in partnership with the Panhandle-Plains Historical Museum (PPHM) at West Texas A\&M University (WTAMU) in Canyon, Texas to better understand and help preserve the cultural resources contained within. This paper compiles information about past archeological investigations from project files and related records on file at both TPWD and PPHM. It draws heavily, but not exclusively, on formal permitted projects that have been reported or documented in abstracts and site forms filed with the Texas Historical Commission (THC).

Maps showing exact archeological site locations or project details that may be too sensitive are intentionally omitted to help protect these non-renewable resources. Most known archeological sites were originally recorded with the PPHM numbering system (i.e. A670 for recorded prehistoric archeological site 670, or H12 for recorded historic site 12) and later issued a number based on the Smithsonian Trinomial System (i.e. 41AM2). This frequently used system of assigning unique numbers to archeological sites is tripartite: the first digit(s) signifies the state (Texas is alphabetically the $41^{\text {st }}$ of the 48 contiguous states), the letters are a code for the county within the state, in this case Armstrong County, and the trailing digit(s) represent the order in which that site was recorded for that county.

This article begins with a short background on the history of the park and a general culture history of the region. It then traces four distinct phases of archeological investigations from the park's inception to the present-day. These include the creation of the park and initial studies in the 1930s-1940s, the outdoor classroom and legislative mandates of the 1950s-1970s, the rise of cultural resource management and permitted projects in the 1980s-2000s, and the park expansion and resulting impact-driven projects of 2010 to the present. The final section discusses how changes in cultural resource management, archeological methods, and technology have shaped both the amount and types of projects conducted at PDCSP. 


\section{PARK BACKGROUND AND CULTURE HISTORY Environmental and Archaeological Setting}

\section{Park History and Boundaries}

Straddling Armstrong and Randall counties in the Texas Panhandle, PDCSP is bisected by the Prairie Dog Town Fork of the Red River. The park is easily accessed via a 12 mi drive east of Canyon, Texas. The state park comprises only a small part of the entire canyon, known anecdotally as the Grand Canyon of Texas, which stretches $20 \mathrm{mi}$ wide, $120 \mathrm{mi}$ long, and 500-600 ft deep. The park was acquired by the Texas Parks Board in 1933 and opened on July 4, 1934 with 15,103 acres.

TPWD has acquired several tracts of land adjacent to the park in the ensuing years, extending PDCSP to the present boundaries. The park added three tracts on the west side of the canyon totaling 940 acres in 1973 and another tract of 267 acres on the east side by 1975. In late 2001, TPWD obtained Canoncita Ranch to the southwest from the Amarillo Area Foundation. This addition of 2,036 acres brought the total park acreage to 18,438 (Beckcom and Barclay 2003). In May 2005, the Amarillo Area Foundation again helped to finance an additional parcel of 7,837 acres on the southeast side of PDCSP purchased from the Harrell Ranch, also known as the Old Home Camp (or 'Old Home Ranch') and was part of the famous original JA Ranch.

The most recent acquisition is the Fortress Cliff Ranch (also known as the Gaynor Ranch) on land adjacent to the northeast. In 2008, TPWD obtained the 2,867-acre ranch to protect the $5 \mathrm{mi}$ face and rim of Fortress Cliff, which dominates much of the viewshed within the park. The ranch had been on the market for over a year, and the concern was that any future housing development along the rim would impact the view. The plan from the outset was to evaluate the new purchase and sell the areas with the least significance to the park's mission. After modeling the viewshed, evaluating recreational access, and considering public use options, TPWD sold approximately 2,014 acres of the recently acquired ranch, primarily grassland with some cedar brush and a side canyon complex known as Tub Springs Draw. The sale tract included a quarter-mile set-back along the canyon rim and was restricted by a Conservation Easement held by TPWD. The primary elements of the easement are that the property can only be subdivided into two tracts in the future, no development can occur near the rim, valuable natural and cultural resources on the property are to be preserved, and the terms of the easement will run with the land in perpetuity.

The purchase of the Fortress Cliff Ranch ultimately added 853 acres to the PDCSP. The park currently encompasses approximately 27,128 acres (Figure 1) and is the second largest operating state park in Texas behind Big Bend Ranch State Park, which encompasses over 300,000 acres. 


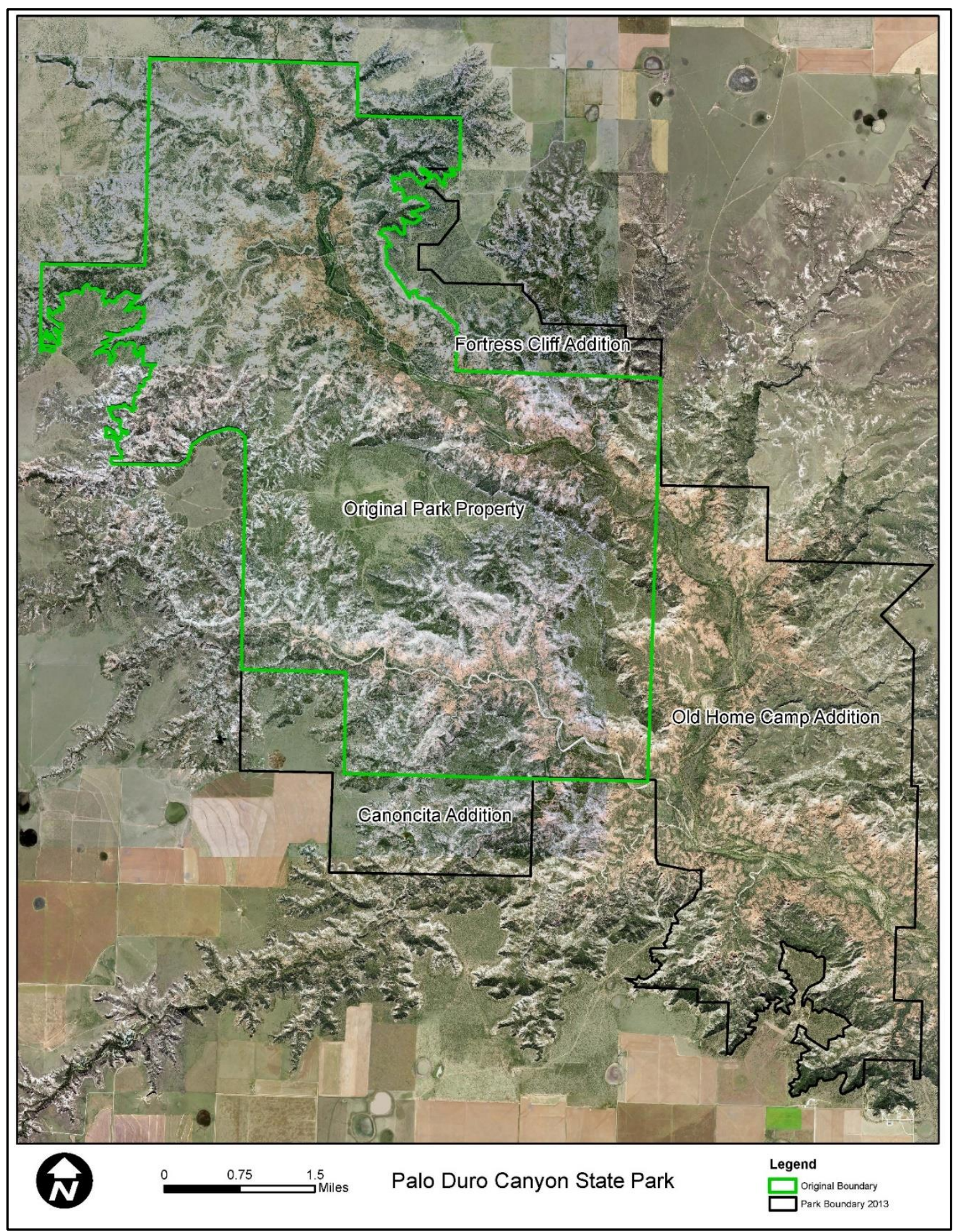

Figure 1. Map showing original boundary and later additions to Palo Duro Canyon State Park.

Palo Duro Canyon State Park (originally known as SP 14 or State Park 14) was developed with the aid of the CCC from July 1933 to December 1937. The National Park Service (NPS) selected the construction projects and supervised the work. An early map compiled in January 
1934 from the Department of Interior's State Park Emergency Conservation Work documents park infrastructure and roads at that time (Figure 2). It also has illustrations on the margins drawn by three local artists, Margaret Seewald, Amy Miears Jackson, and Ben Carlton Mead, of prominent landscape features and historical scenes from AD 1540-1934. These artists contributed their work for free to help boost park visitation (G. Carlander to D.E. Colp, letter, 23 February 1934, Carlander Papers, PPHM Archives, Canyon, TX). The map was widely distributed to various Chambers of Commerce and automobile clubs throughout the region to promote the park (personal notes, 28 February 1934, Carlander Papers, PPHM Archives). Until March 1947 when the Texas State Park Board finally bought all adjoining private lands within park boundaries, the solvency of the state park depended on tourism and entrance fees (Petersen 1978).
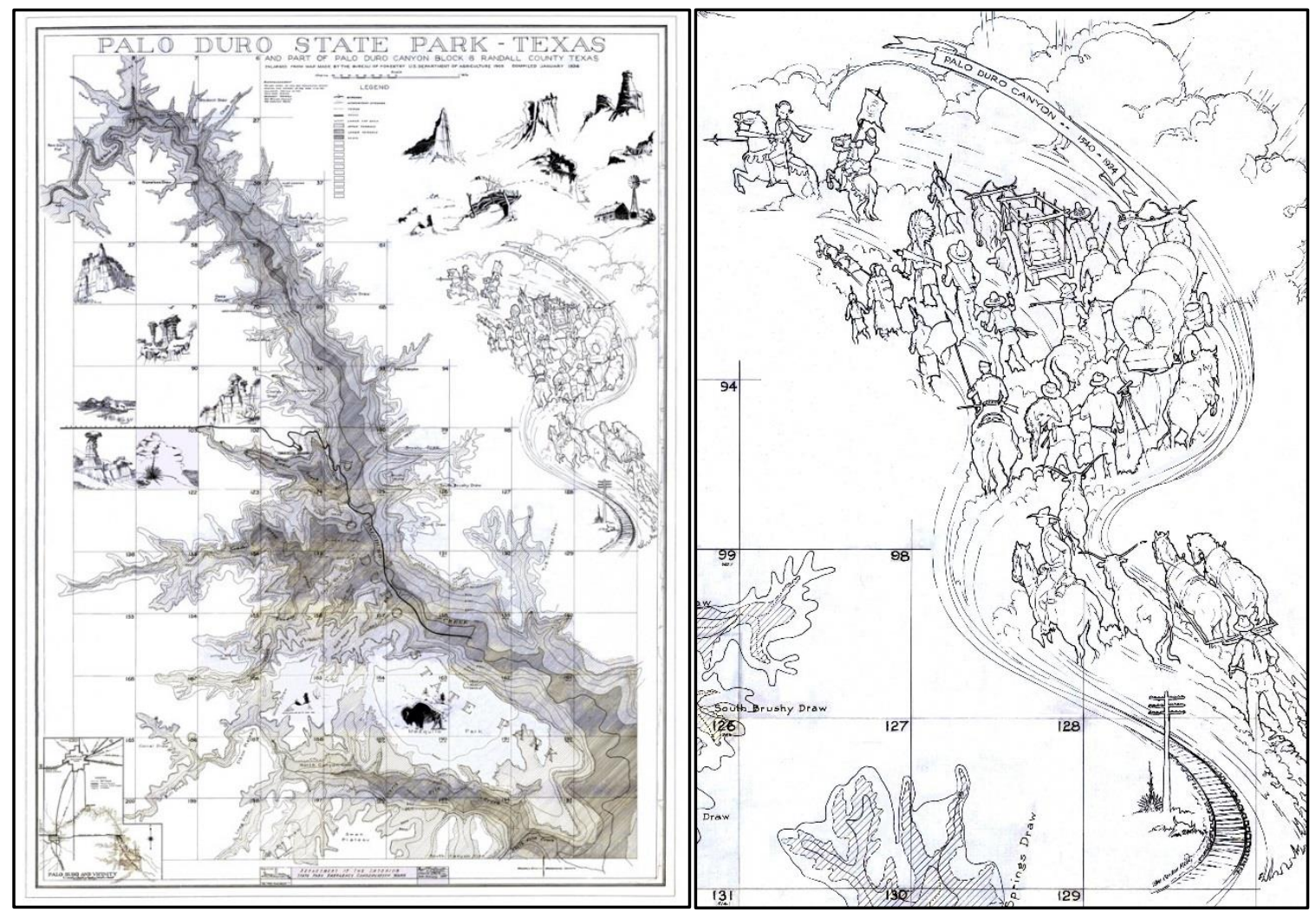

Figure 2. 1934 map of Palo Duro Canyon (I) with close-up of artwork depicting early historical scenes (r). Adapted by Christopher Lintz from the Department of Interior State Park Emergency Conservation Work (1934) compiled map. Courtesy of Texas Parks and Wildlife Department.

Since its inception, various commercial undertakings have taken place within the park to help promote tourism. Each development has left a distinct cultural signature at PDCSP which may eventually have bearing on the archeological record. A few of the more prominent short-lived promotions include the coin drops of 1949-1951, the on-scene filming of the movie The Sundowners in 1950 (Amarillo Daily News [ADN], 30 January 1950:1), and weekend dancing events held on a concrete platform near Water Crossing \#1 during the 1950s (The Canyon News [CN], 21 June 1951:1). The coin drop was part of a treasure hunt by the Palo Duro Booster Club, whereby 10,000 dated brass Goldine coins were dropped from an airplane in 1949, again in 1950, and with a mix 
of foreign coinage (Peruvian and Mexican) in 1951 (Harrison 1993:3; The Claude News, 20 May 1949:1-2). The coins were individually numbered, and visitors who found certain numbers were awarded prizes donated by area merchants or eligible to enter drawings for the Grand Prizes $(\mathrm{CN}$, 31 May 1951:1; Curry 1950:3). Some of these coins have since been recovered by more recent visitors (Foss 1978) or in archeological survey (Shaller et al. 2013).

The Sad Monkey Railroad was a narrow-gauge railroad for tourists that ran from 1953-1998 in PDCSP (Beckcom and Barclay 2003). Officially named the Palo Duro, Burlington \& Sad Monkey Railroad, the name derived from a rock formation near the top of Triassic Peak that appeared to resemble the face of a sad monkey. The locomotive pulled 4-5 passenger cars slowly through a 2-mile course that started at the covered train station near Triassic Peak and wound its way through the Timber Creek area and towards the Christmas Tree Canyon before returning to the station 20 minutes later (Bowers 2019). With a capacity for 30 passengers and a tour guide that would point out distinctive geologic and historical features along the route, the railroad was a popular attraction for over 40 years (Figure 3 ). Although the train and track were dismantled and completely removed from the park property, its route is still visible on old USGS topographic maps (Fortress Cliff) and the refurbished locomotive is presently on display near the town square in Canyon.

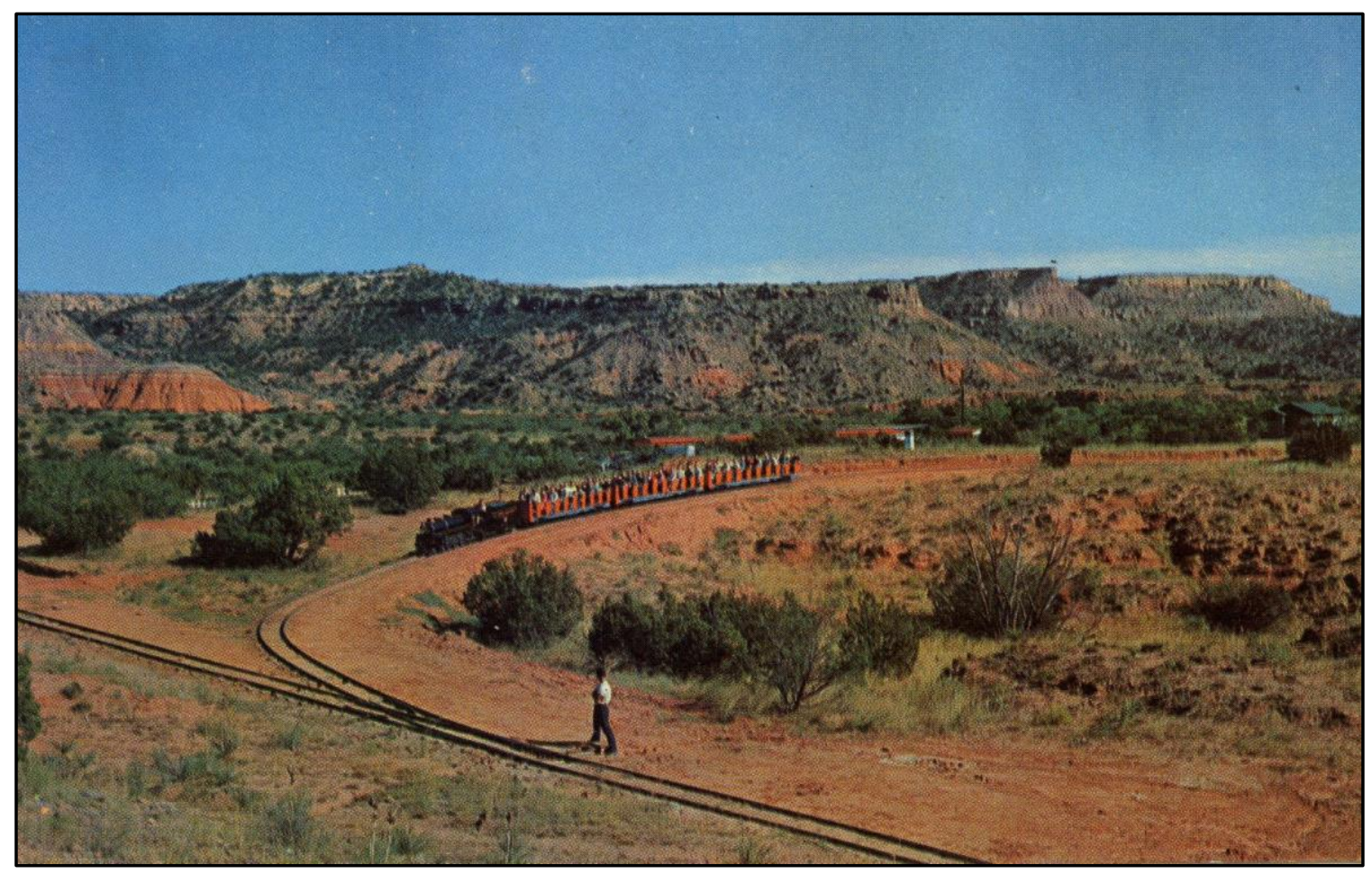

Figure 3. Photograph of Sad Monkey Railroad postcard. Undated postcard from the scrapbook of Sarah Elizabeth Thompson, courtesy of Panhandle-Plains Historical Museum Archives. 
Another park tourist attraction that left a visible footprint was the Sky Ride chair lift that was operational from 1959 to ca.1972 (Figure 4). The Sky Ride, purchased and installed by long-time park concessionaire Pete Cowart, was operational during the summers, holidays, and weekends (Knorpp 2016). From its base near Water Crossing \#1 near the present-day Givens, Spicer, Lowry trailhead, the Sky Ride transported visitors $300 \mathrm{ft}$ from the canyon floor to an observation platform located on top of Timber Mesa (Beckcom and Barclay 2003:7; Vertical Files, PPHM Archives). Although safety concerns led to its closure, remnants of concrete foundations at the location of the lower drive bullwheel and the intermediate supporting towers leading to the top remain visible, as well as a gouge cut into the caprock near the top of Timber Mesa.

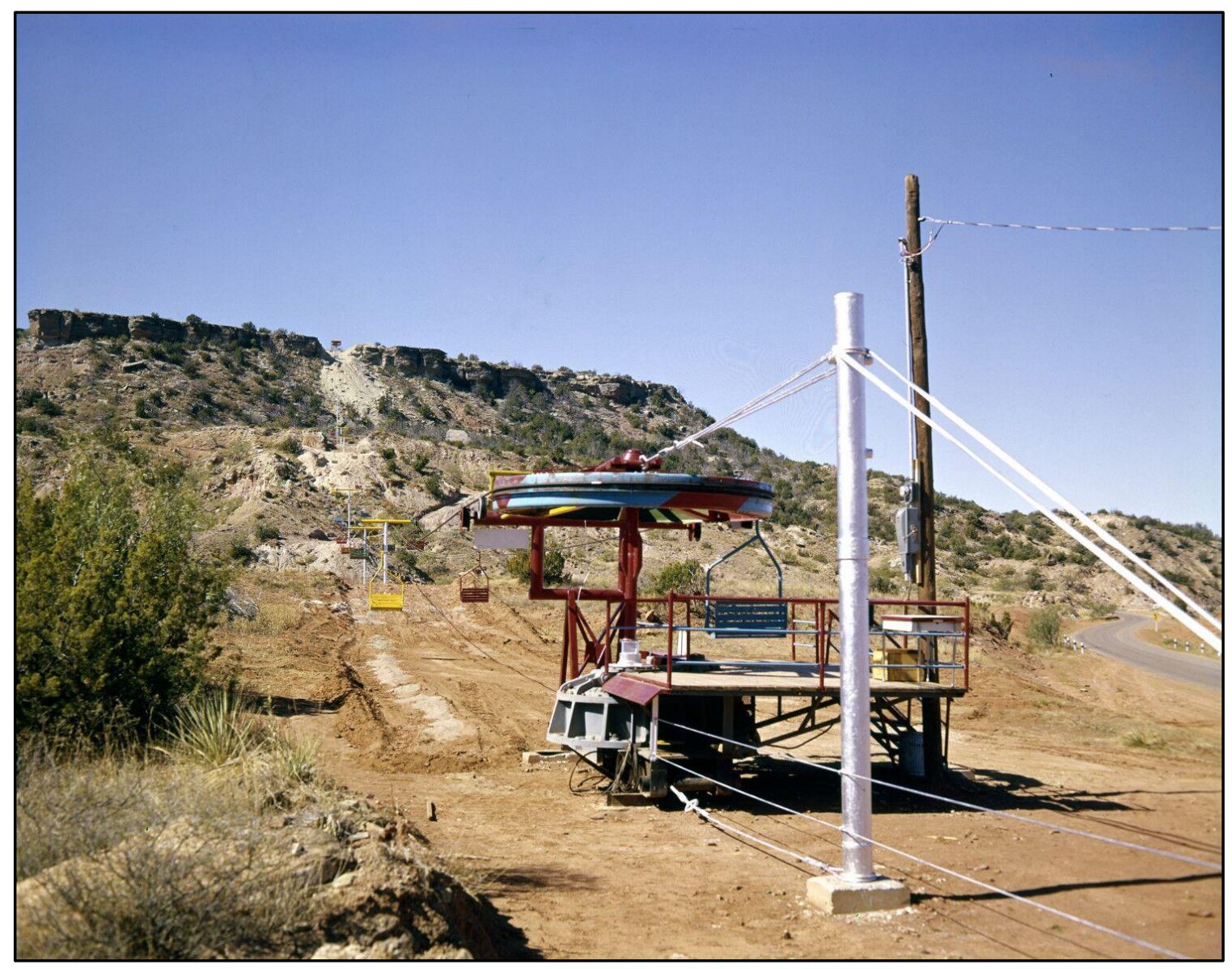

Figure 4. Undated photograph of the Palo Duro Canyon Sky Ride extending from the canyon floor to Timber Mesa. Photograph by Bill Bradly (n.d.), courtesy of Deaf Smith County Library.

The CCC built structures, the lodge and cabins, have been enduring parts of the cultural landscape of PDCSP. The El Coronado Lodge and three cabins along the rim along with four "Cow Camp" cabins in the lower part of the park were constructed by the CCC using Trujillo Sandstone quarried nearby and fashioned into stone masonry. Approximately 45,000 $\mathrm{ft}^{3}$ of rock and sediment were removed, some with explosives, to create the stone bench foundation 
supporting El Coronado Lodge, which was not fully developed by the time CCC workers left the park in 1937 (Jackson 2013). It served as the park's concession-souvenir shop during the 1950s1960s until the Goodnight Trading Post (also known as "The Chuckwagon") on the canyon floor opened in 1966 (Beckcom and Barclay 2003), although it sat idle for several years until drainage issues could be addressed (Marcy 1972:31). It now houses the Visitor's Center, gift shop, and offices (Beckcom and Barclay 2003). Beginning in the 1990s, much development has occurred to rehabilitate the cabins that had long been neglected, as well as adding new campgrounds and restrooms.

The amphitheater at PDCSP opened in 1963 with the objective of featuring an outdoor theater production about early life in the Texas Panhandle. From its first use for Easter sunrise services on April 14, 1963 to short-lived productions of "Fandangle" in 1964 and "Thunder Sounds of the West" from June-September 1965 to the still running musical TEXAS that debuted on July 1, 1966, it continues to attract and impress visitors from around the world every summer (Guy 2001). The nearby Mack Dick Pavilion, a 4,080 $\mathrm{ft}^{2}$ events and rental facility, opened in April 2012 (Welch 2012), while construction for the $1,200 \mathrm{ft}^{2}$ Tasajillo Pavilion at the southern end of the park was completed in 2016.

In addition to these structures, horse stables have been a part of PDCSP since its inception. Early on, the stables were presumably located on the rim, perhaps near the current entry, while CCC workers began building roads, hiking trails, and horse trails. An early trail started just behind

El Coronado Lodge and switchbacked to the canyon floor. Later, the stables moved down onto the canyon floor, operating for a time as the Lighthouse Stables at the site of the current Mack Dick Pavilion and later in 1999 through the present as the Old West Stables at the previous location of the Sad Monkey Railroad (Mark Hassell, personal communication 2019).

\section{Regional Culture History}

An abbreviated regional culture history is included here to provide some context to the human history of PDCSP. Jack Hughes's overview of the archeology of Palo Duro Canyon (Hughes 1978, reprinted in 1979 and 2001) brought together the significant archeological finds in Palo Duro Canyon to that date. Since then, there have been some refinements to the general timeline of human occupation in Palo Duro Canyon and the surrounding Panhandle Plains region. Comparable, but not identical cultural chronologies of the region and adjoining areas are provided in detail elsewhere (Boyd 1997, 2004; Gunnerson 1987; Hicks 2001; Hicks and Lyle 2013; Mercado-Allinger 2004; Pertulla 2004; Quigg et al. 2010). In the late 1970s, common taxonomies for the region followed Hughes' use of the Paleoindian, Archaic, Neoindian, and Historic Periods. By the 1990s, this taxonomy had been revised into the current generally accepted scheme and applied to studies in and near PDCSP. Five general culture periods are recognized for the Panhandle Plains region in which Palo Duro Canyon State Park is located: Paleoindian, Archaic, Ceramic, Protohistoric, and Historic Periods. The majority of aboriginal or Native American sites 
known within the region are surface occurrences representing single-occupation utilization of local resources, but numerous multi-component sites in good stratigraphic context have also been studied. The range of dates given in this discussion are in years before present (BP), except for the protohistoric and historic periods which will be given in calendar dates (AD).

\section{Paleoindian Period (11,500-8500 BP)}

The types of sites often identified during the Paleoindian Period (11,500-8500 BP) include large game animal kill sites, butchering locales, and caches. The subsistence patterns were broad-based with early Paleoindian peoples hunting a wide variety of now-extinct large game animals and later groups focusing on bison procurement (Johnson 1987). Most of the well-preserved sites have been found in deep canyon waterways, such as Lubbock Lake and Lake Theo in the Southern Plains and Blackwater Draw in eastern New Mexico. Isolated finds of Clovis and Folsom points, primarily basal fragments, have been reported by Hughes (1978), as well as more recently in 2014 on private property just outside the state park boundary on the upland rim by staff archeologists at PPHM. Bison antiquus remains were found in association with Plainview and side-notched points approximately 25 miles south of the park in Tule Canyon (Willey et al. 1978). Also, a rare Plainview-age campsite has been reported (Mallouf and Mandel 1997) in the Canadian River Valley of the Texas Panhandle (approximately 100 miles northeast of Palo Duro Canyon).

\section{Archaic Period (8500-2000 BP)}

The Archaic Period (8500-2000 BP) covers a long-time span of prehistory and subdivides into the Early, Middle and Late Archaic. The entire Archaic Period has a distinct artifactual signature typified by a variety of notched and stemmed projectile points, grinding equipment for processing plants, roasting ovens and rock-lined hearths, and faunal assemblages that include only modern species (Holliday 1997). Archaic sites found within the area include kill/butchering sites, campsites, rockshelters, and burials. Much of the Early and Middle Archaic coincide with the Altithermal, a period of prolonged drought and intense erosional activity which in turn affected site preservation. Only surface finds of projectile points are indicative of the earliest period (Katz and Katz 1976). The Middle Archaic is characterized by subsistence changes that correspond to a changing environment, as the importance of plant processing grew and populations became increasingly tied to dwindling water resources. The earliest component of Chalk Hollow, a deeply buried, stratified open campsite along the northern rim of Palo Duro Canyon, dated to the Middle Archaic (Lintz 2002; Quigg et al. 2010), while the Bitter Creek site in Hall County (approximately 40 miles downstream) is also thought to date to this timeframe (Hughes and Hood 1976). Late Archaic sites are more plentiful within Palo Duro Canyon, several of which lie within the park boundaries. An important type site occurring just outside the park boundaries is the Little Sunday site, though known from surface collections alone (Hughes 1955, 1991). Boyd expanded the Little Sunday complex to include additional sites with dated components ranging from ca. 1500-800 BP and characterized the culture as a semi-sedentary group who exploited a wide range of locally available seasonal resources (Boyd 1997). Summarizing the Archaic Period, Quigg et al. state that, "very little is known about Archaic sites in the Texas Panhandle and in the adjacent area of the 
Plains due to the general lack of excavated sites dating earlier than 2000 BP" (2010: 63). Severe erosion may also contribute to the scarcity of known Early and Middle Archaic deposits (Quigg et al. 2010). This is assumed to be the case within Palo Duro Canyon and the state park, however, future geoarcheological studies should help inform on the matter.

\section{Ceramic Period (2000-550 BP)}

The Ceramic Period (2000-550 BP) is a time of transition and technological change brought about by the introduction of ceramics and the bow and arrow. The co-occurrence of both dart and arrow points at various sites during the Early Ceramic Period, also referred to as the Late Prehistoric I (Boyd 1997, Quigg et al. 2010), suggests that both the atlatl and the bow and arrow coexisted for a very long time, perhaps as a consequence of the persistence of bison as a major food resource in this region (Tomka 2013). Cultural expressions of both Plains Woodland and Jornada Mogollon overlap in the Texas Panhandle during this time period. The Lake Creek site defines a complex of poorly understood sites found mostly north of the Canadian River that have Woodland characteristics, mainly small corner-notched (Scallorn) arrow points and distinctive cord-marked pottery with elongated forms and conical bases (Quigg et al. 2010). South of the Canadian River and centered in the upper drainages of the Red and Brazos rivers are sites characteristic of the Palo Duro Complex. These sites range from short-term camp sites to rockshelters to residential sites and have associated artifact assemblages that often include, but are not limited to, long stemmed corner-notched arrow points (Deadman), Mogollon brownware pottery, and Clear Fork gouges (Boyd 2004). The type and degree of cultural interaction between Plains Woodland and Southwestern-influenced peoples is unknown; however, most of their spatial overlap lies between the Canadian River and the Prairie Dog Town Fork of the Red River (Boyd 2004: 325).

The Middle Ceramic Period, also referred to as the Late Prehistoric II (Boyd 1997, MercadoAllinger 2004; Quigg et al. 2010), is dominated by distinctive Plains Village architecture and artifact assemblages. Along the Canadian River valley, hundreds of sites ranging from small isolated houses to villages associated with the Antelope Creek Focus have been documented. Some of the associated traits include stone slab/wall post houses, side-notched arrow points (Washita and Harrell), unnotched arrow points (Fresno), and globular cord marked pottery known as Borger Cordmarked (Lintz 1986). While no Antelope Creek Phase sites have been found within PDCSP boundaries, a few sites have been reported within the canyon on the nearby Harrell Ranch (A442, PPHM site files) and in the lower Tule Canyon (Malone 1970; J. Hughes 1991). Other sites in the Texas Panhandle have classic Antelope Creek traits but contain non-masonry, picket post houses. In the northeastern corner of the Texas Panhandle, the Buried City Complex has been defined along Wolf Creek (Hughes and Hughes-Jones 1987; D. Hughes 1991).

Palo Duro Canyon continued to be a focal point of cultural activity from approximately 400200 years ago throughout the Protohistoric Period. During this time period (AD 1541-1750), also referred to as the Late Ceramic Period (Gunnerson 1987), Palo Duro Canyon was along a geographic dividing line between the Tierra Blanca Complex to the north and the Garza Complex 
to the south. Although similar in many respects, the Tierra Blanca peoples had more permanent shelter and utilized Alibates agate, as opposed to Edwards Plateau chert, as their primary lithic source material. Tierra Blanca sites contain no Garza or Lott points, which are common at Garza Complex sites (Hicks and Lyle 2013). The relationship between these cultural complexes and indigenous (Boyd 2004), Southwestern (Rio Grande Pueblo, see Habicht-Mauche 1988, 1991) and eastern peoples (Edwards Complex/Wheeler Phase, see Baugh 1992) is still in question. Only Tierra Blanca Complex Protohistoric sites have been recorded within the park (Hicks 2001; Hicks and Lyle 2013). Other Protohistoric events in the Panhandle Plains area include the Entrada by Coronado and later Spanish expeditions.

\section{Historic Period (AD 1750 to the present)}

The Historic Period (AD 1750 to the present) includes indigenous horse cultures including the Comanche, Kiowa, Kiowa-Apache, and Cheyenne that came into the region after adopting the horse following the Pueblo Revolt of 1680. These groups termed the "Equestrian Nomad Complex" by Shafer et al. (1991) left sites with tipi rings, metal files, knives, arrow points, lances, bracelets, and horse gear. Nonindigenous occupation of the Southern High Plains and Rolling Plains in the 1860s, notably the incursion of ciboleros (Hispanic and Pueblo Indian) and Anglo buffalo hunters, comancheros (Hispanic traders from New Mexico, see Guffee 1976), U.S. military units, pastores (Hispanic sheepherders from New Mexico, see Hicks and Johnson 2000; Taylor 1984) and cattle ranchers such as Charles Goodnight (Haley 1981) all left an imprint in PDCSP. Major portions of the 1874 Battle of Palo Duro Canyon are known to have taken place within the park and a dugout site that was probably used as a line camp has also been excavated (Roberson and Ing 1973).

Archeological sites and features have been noted as early as the 1930's on CCC maps of Palo Duro Canyon. However, most of the known archeological sites at PDCSP were recorded by archeologists from PPHM and West Texas State University (now WTAMU) from the 1950s1980s. To date, there are 46 sites officially recorded using trinomials within the park. 


\section{PHASES OF ARCHEOLOGICAL INVESTIGATIONS Creation of the Park and Initial Studies: 1930s-1940s}

Very little archeological work occurred in Palo Duro Canyon State Park before the NPS and the CCC's involvement in park development. Known sites were remote and difficult to access, and there were few trained archeologists in the area. An early amateur archeologist who would play an important role in the development of both PDCSP and PPHM was Floyd V. Studer.

Floyd Studer (1892-1966), a native of Canadian, Texas, moved to Amarillo in 1925 and became an influential businessman and civic leader. As a teenager, he accompanied his principal and science professor, T.L. Eyerly, and classmates at the Canadian Academy to investigate the stone ruins of the Buried City on Wolf Creek in Ochiltree County, Texas in 1907 (Rathjen 2010; Studer 1931). The Buried City is a large Ceramic Period archeological complex, and the site of the first reported excavations in the Texas Panhandle. Studer's participation in this excavation sparked a lifelong interest in the archeology and paleontology of the Texas Panhandle and the Canadian River Valley.

From then on, Studer made numerous field trips to archeological sites in Palo Duro Canyon and across the region to familiarize himself with the breadth and diversity of cultural material. Even after entering a career in banking and then insurance administration, he would visit archeological and paleontological sites in his spare time, record their locations, and make contacts with professional archeologists across the country (Rathjen 2010 ; Studer 1931). As a self-trained, local authority in these scientific disciplines, he was among the earliest supporters of the Panhandle-Plains Historical Society, first organized in 1921, and the establishment of PPHM in 1933 to house the Society's collections. His involvement led to his appointment prior to 1932, as the museum's first Director of Archeology and Paleontology, an unpaid, off-hours position responsible for the acquisition and exhibition of artifacts at the museum.

By the time of the park's creation, Studer had already visited and recorded many archeological sites in the canyon and adjoining areas. He was familiar with many of the rock art and mortar hole sites at Palo Duro Canyon (Studer 1934). To him, the canyon was "a natural outdoor laboratory, with all of our specimens and objects of study about us in profusion (Studer 1939:3)." Existing museum records indicate that he recorded his sites numerically on index cards, placed additional information about the individual sites on another set of index cards, and plotted their locations on Oil and Gas Plat maps, where one inch on the map equaled $2.5 \mathrm{mi}$. While some of these records still exist, many have been misplaced in the intervening years, leaving gaps in his sequence of recorded sites.

Studer began partnering with the NPS and Texas Park Board in 1934 for the curation and exhibition of park artifacts. Early that year, he offered to serve as a scientific curator of the proposed 
park museum without pay; an offer accepted by David E. Colp, the first Chairman of the State Park Board (D.E. Colp to F. Studer, letter, 8 March 1934, Carlander Papers, PPHM Archives). In recommending Studer for this position, Amarillo architect Guy Carlander wrote that "Mr. Studer is nationally known in all of the larger museums and has written several scientific papers published by Yale University" (G. Carlander to D.E. Colp, letter, 17 February 1934, Carlander Papers, PPHM Archives). Once onboard, Studer started by exhibiting some of the park's archeological materials at the PPHM (Studer 1934). He also worked with park employee, J.B. Elliston, on an artifact exhibit from Palo Duro Park to be displayed at the Amarillo Hotel in 1934 (G. Carlander to D.E. Colp, letter, 18 December 1934, Carlander Papers, PPHM Archives) (Figure 5). These displays would have brought much needed publicity to PDCSP, which was struggling to raise park visitation and the income necessary to pay off acquisition debts (Petersen 1978).

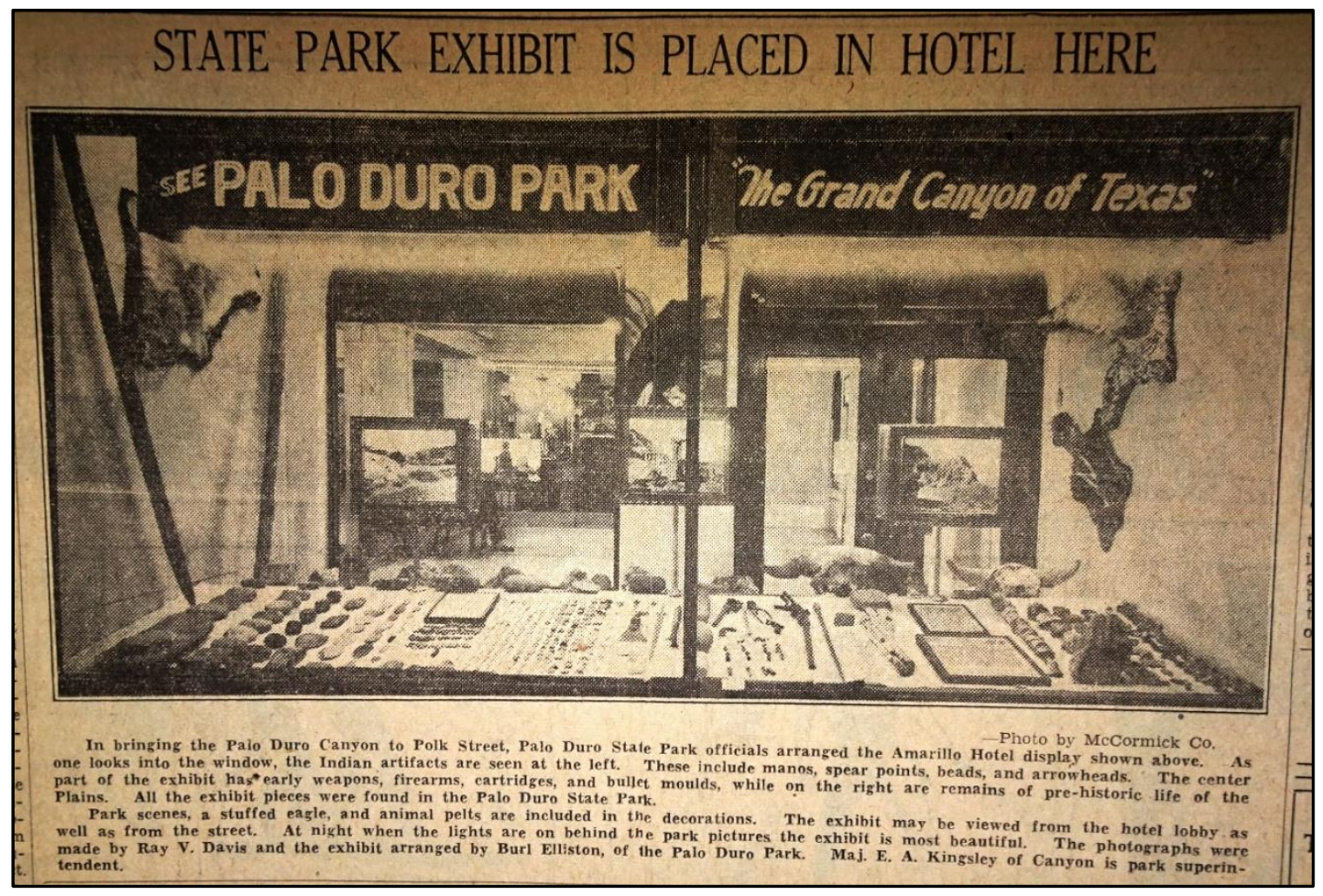

Figure 5. Artifacts found at Palo Duro State Park and exhibited at the Amarillo Hotel. Amarillo Sunday News and Globe, January 13, 1935.

In addition to these exhibits, archeological artifacts found at the park were also on display at a temporary museum within the park (Reed 1936). Correspondence in August 1934 between Studer, Colp, and Carlander discuss the need for building suitable exhibit cases and provide specifications for materials, sizes, and glass for the cases (Carlander Papers, PPHM Archives). This on-site museum served multiple purposes. Apart from showcasing "relics" to park visitors, Studer, Carlander and others hoped that by prominently displaying the artifacts with their proper identification and the name of the person who had found them, CCC enrollees working at the park 
would turn in their finds to the museum rather than keeping them. Studer writes to Carlander that "this material properly displayed would certainly encourage others to turn in material that is still being gathered in the Canyon, and most of which, in my opinion, is leaving the Canyon forever" (letter, 6 August 1934, Carlander Papers, PPHM Archives). In the long-term, he believed that PDCSP should become a national monument managed by the NPS, with a permanent museum located in the canyon to preserve and exhibit artifacts and specimens found there (Studer 1939).

During his tenure at PPHM, Studer reportedly recorded over 200 archeological sites and several paleontological sites in the Texas Panhandle. According to some of his site records, he named archeological sites in PDCSP after employees and military personnel stationed at the CCC camp. Studer also collected artifacts from several of the sites he had visited. Some of these artifacts were cataloged into the scientific collections at PPHM, while others he retained for his private collection at home. Upon his death in 1966, most of his private collection and records were distributed among the Alibates Flint Quarries National Monument, the NPS, and PPHM. The Studer material belonging to the NPS is presently at PPHM as a federal held-in trust collection.

The earliest official report on the cultural resources at PDCSP was written by archeologist Erick Kellerman Reed in 1936. Reed (1914-1990) was born in Massachusetts and formally trained as an anthropologist in the Northeast. He received his anthropology degrees from George Washington University (B.A. 1932) and Harvard (M.A. 1933 and Ph.D. ca. 1945). Before joining the NPS as a seasonal ranger in 1935, he worked on several archeological sites in the Southwest, including the Harris Site in the Mimbres Valley in southwestern New Mexico and Snaketown in Arizona under the renowned archeologist Emil W. Haury (Steen 1981).

In August 1935, Reed took a position with the State Parks Division of the CCC supervising several archeological projects. It was likely then that he worked on the baseline study of the archeological sites and artifacts at PDCSP. In his short report, he lists 16 archeological sites that had been found within park boundaries. He details some of the artifacts found at those sites and provided locational data. Reed writes in his report that the sites "were observed and recorded, and additional specimens secured," while alluding to parts of the park that had already been surveyed by Studer (Reed 1936:2).

Reed worked with Studer and others to educate the CCC workers about the problems with personally collecting archeological and paleontological materials from the park. Programs and lectures were given on the importance of these finds, and workers were encouraged to turn in their finds to park foreman J.B. Elliston (G. Carlander to D.E. Colp, letter, 9 August 1934, Carlander Papers, PPHM Archives). Reed recommended in his report the creation of a permanent museum at the park that would complement PPHM by exhibiting archeological, paleontological, and historical materials from Palo Duro Canyon. In the summer of 1936, West Texas State Teachers College student, William M. Pearce, was hired to record and catalog the material that had been turned in to officials and to do a general archeological survey within the park (Reed 1936). Pearce 
recorded these artifacts in a ledger book that contains 2,866 entries. The ledger book and many of the associated artifacts are now at PPHM, while some of these artifacts remain on exhibit at the Interpretative Center at El Coronado Lodge in PDCSP.

By the summer of 1936, Reed had moved on to other archeological projects away from the Texas Panhandle. After doing some survey work in the area that would later become Big Bend National Park, he went on to become a regional archeologist for the National Park Service, where he worked until his retirement in 1969.

James Byrle (J.B.) Elliston (1885-1973) worked in association with Studer and Reed on collecting and recording archeological specimens collected within PDCSP (Figure 6). Elliston was in the real estate business in Hereford before moving to Canyon for a few years. While in Canyon, he served as the assistant chairman of the State Parks Board from 1929-1932 and president of the Canyon Chamber of Commerce in 1932, where he worked to establish Palo Duro as a state park (Deaf Smith County Historical Society 1982:118). Later, he was employed by the park as a foreman until early 1936 (Reed 1936). Elliston was an avid collector of Native American artifacts and eventually moved back to Hereford, where he joined the Deaf Smith County Chamber of Commerce (Deaf Smith County Historical Society 1982:118).

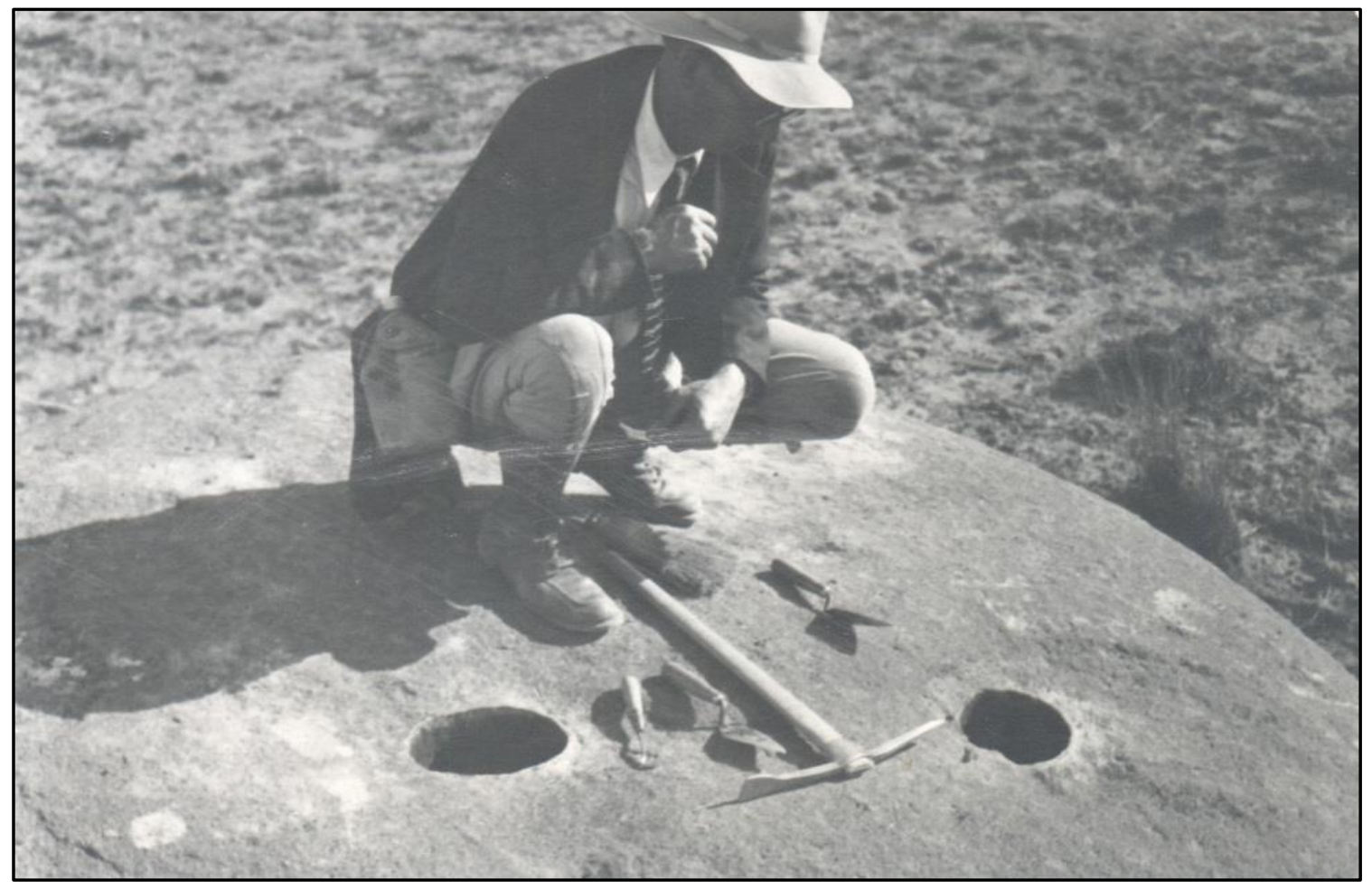

Figure 6. J.B. Elliston at mortar hole site near Cow Camp at Palo Duro Canyon ca. 1934. Courtesy of Panhandle-Plains Historical Museum.

There is little evidence that much archeological work was done in PDCSP in the 1940s. For much of the decade, the future of Palo Duro Canyon as a state park remained in question. The last 
of the CCC workers had left in December 1937, and little maintenance had been done to the road or park facilities since. Park visitation dropped as the park became encumbered in even more debt and the demands of World War II led to gas rationing (Petersen 1978).

\section{Outdoor Classroom and Legislative Mandates: 1950s-1970s}

It was during the 1950s-1970s that Floyd Studer's vision of PDCSP as an outdoor laboratory or classroom for archeology became a reality. There were more scientific, archeological studies conducted exclusively to better understand the history and prehistory of the canyon during this time than at any other period before and after. The event that precipitated this major shift was the arrival of Jack T. Hughes to the Panhandle-Plains Historical Museum and the then West Texas State College (WTSC).

Jack Hughes (1921-2001) had been raised in northern East Texas, where his youth was spent walking the outdoors and observing the natural world. Hughes received his academic training in anthropology and geology at the University of Texas in Austin (B.S. 1937 and M.A. 1942) and Columbia University (Ph.D. 1968). During the 1940s, he worked with Smithsonian archeologist Waldo Wedel on some of the River Basin Surveys across the Northern Plains, a major archeological undertaking directed by the NPS and the Smithsonian Institution.

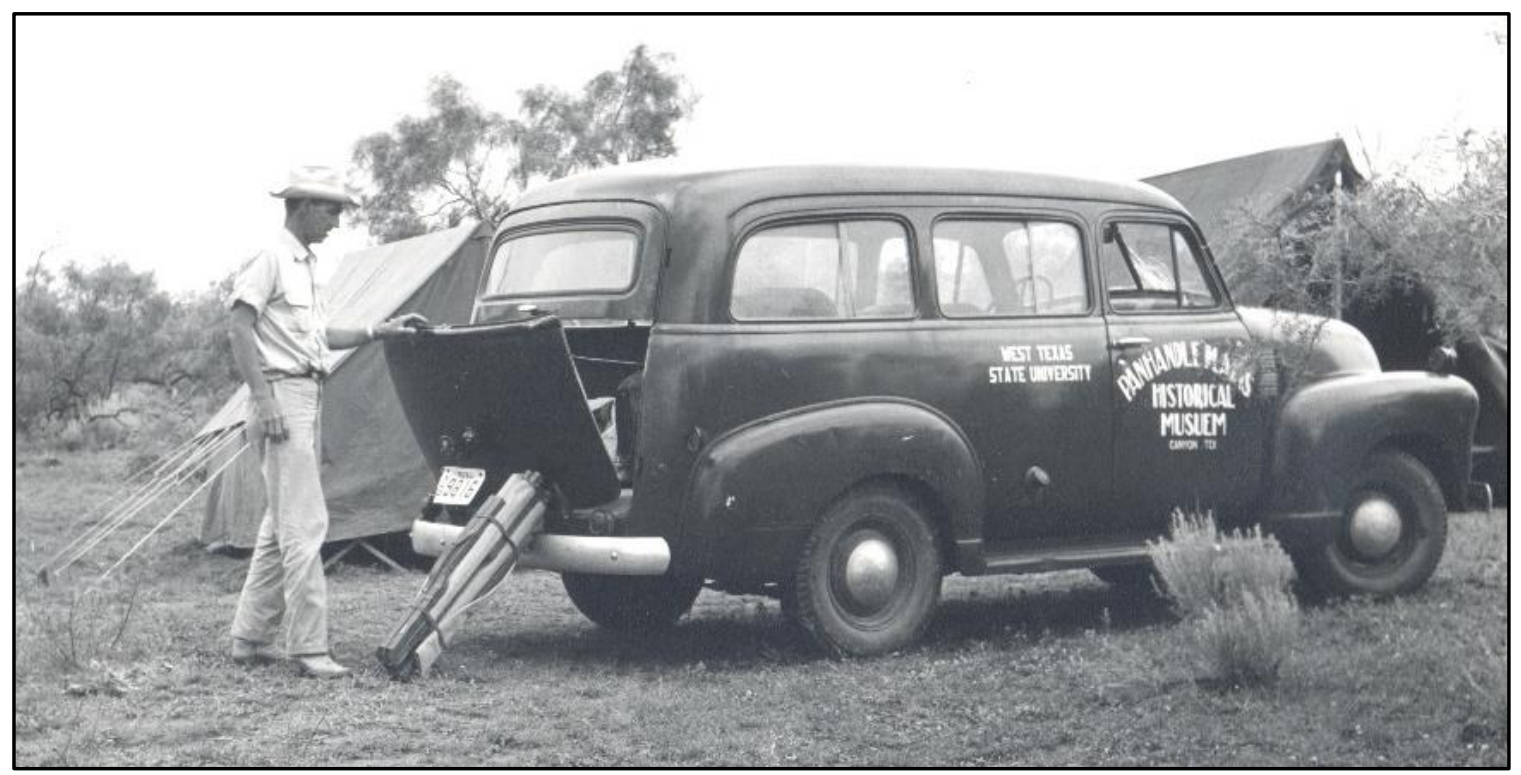

Figure 7. Jack Hughes, former Curator of Paleontology and WTSC professor, on a 1966 field expedition at Old Clarendon in Donley County, Texas. Courtesy of Panhandle-Plains Historical Museum.

WTSC hired Jack Hughes in 1952 as an associate professor in the Geology Department, where he taught both geology and anthropology courses, and served as part-time Curator of Paleontology at the PPHM. Although Floyd Studer continued to hold on to his honorary title of Curator of Archeology until his death in 1966, Hughes became responsible for the curation of the museum's 
archeology, ethnology, geology, paleontology, and biology collections (Figure 7). He remained in this position until 1968, when he became a full-time professor of geology and anthropology and the director of a newly created cultural resource firm at the college, the Killgore Center's Archeological Research Laboratory.

Hughes' contributions to the archeological research of PDCSP were three-fold. First, he recorded and well-documented numerous archeological sites in the region and plotted their locations first on 1936 Texas General Highway county maps (1:125,000 or 1 in on the map equals $10,560 \mathrm{ft}$ or $2 \mathrm{mi}$ ) and, later, on USGS 7.5-minute series topographic maps (1:24,000 or 1 in on the map equals 2,000 ft). His system of recording sites, using the prefixes " $\mathrm{A}$ " for archeological, " $\mathrm{H}$ " for historical, "P" for paleontological, "M" site for mineral (geological), and "Z" for zoological, is still in use today. Apart from filing site forms at PPHM, he kept thorough field notes after each site visit detailing general description, condition, diagnostic artifacts, and topographical setting. Second, Hughes relied heavily on Palo Duro Canyon as a teaching aid, making numerous fieldtrips with WTSC students to study geological formations, archeological patterns, and cultural chronology. He also supervised several student projects including the excavation of the "Goodnight" dugout, the remains of a cowboy line camp or H16 (41RD9) (Tunnell 1962), measuring and mapping mortar hole sites at A92 and A672 (Lutz and Farmer 1968; Speer and Essary 1968), and a thesis that included the only known aboriginal pictographs within the park (Upshaw 1972). Subsequently, a minor test excavation was done at the dugout (H16) by TPWD archeologists to assess restoration options (Roberson and Ing 1973). Third, Hughes trained a generation of students on systematic field methods and data recording, who would then go on to do their own archeological research at the canyon. Those discussed later in the chapter include Billy Harrison, Roberta Speer, A.J. Taylor, Alvin Lynn, Rolla Shaller, and Brett Cruse.

Billy Robert Harrison (1937-1996) was a Canyon native and a geology and anthropology student at WTSC (B.S. 1961). Before becoming an employee of PDCSP and later PPHM, he worked at the multi-component archeological sites of Bonfire Shelter and Arenosa Shelter in the Lower Pecos region of Texas, surveyed and excavated Antelope Creek sites along the proposed Sanford Reservoir in the Panhandle with Dr. Earl Green, and Paleoindian locales in southwestern Alaska. In 1967, TPWD hired him as a park attendant at PDCSP. As Harrison lived within the park, he would use his time off-duty to hike and explore the vast areas of Palo Duro Canyon. It was during these outings that Harrison stumbled upon most of the known archeological sites. Then, either he or Hughes would diligently record them at PPHM, where he later worked as a laboratory supervisor under an NSF grant. When Dr. Hughes moved to a full-time professorship, Harrison succeeded him as the first full-time Curator of Archeology at PPHM in January 1969 (Figure 8).

Harrison continued to make trips to PDCSP to either revisit archeological sites or look for new ones throughout his career at PPHM and into retirement in 1992. In addition, he worked as an independent archeological contractor for the TPWD and conducted several small-scale mitigation 
and monitoring studies in advance of construction projects at PDCSP, Caprock Canyons State Park, and Matador Wildlife Management Area. The next section on permitted projects discusses some of these studies, but they were all the result of major federal and state legislative mandates passed in the 1960s regarding the protection of cultural resources.

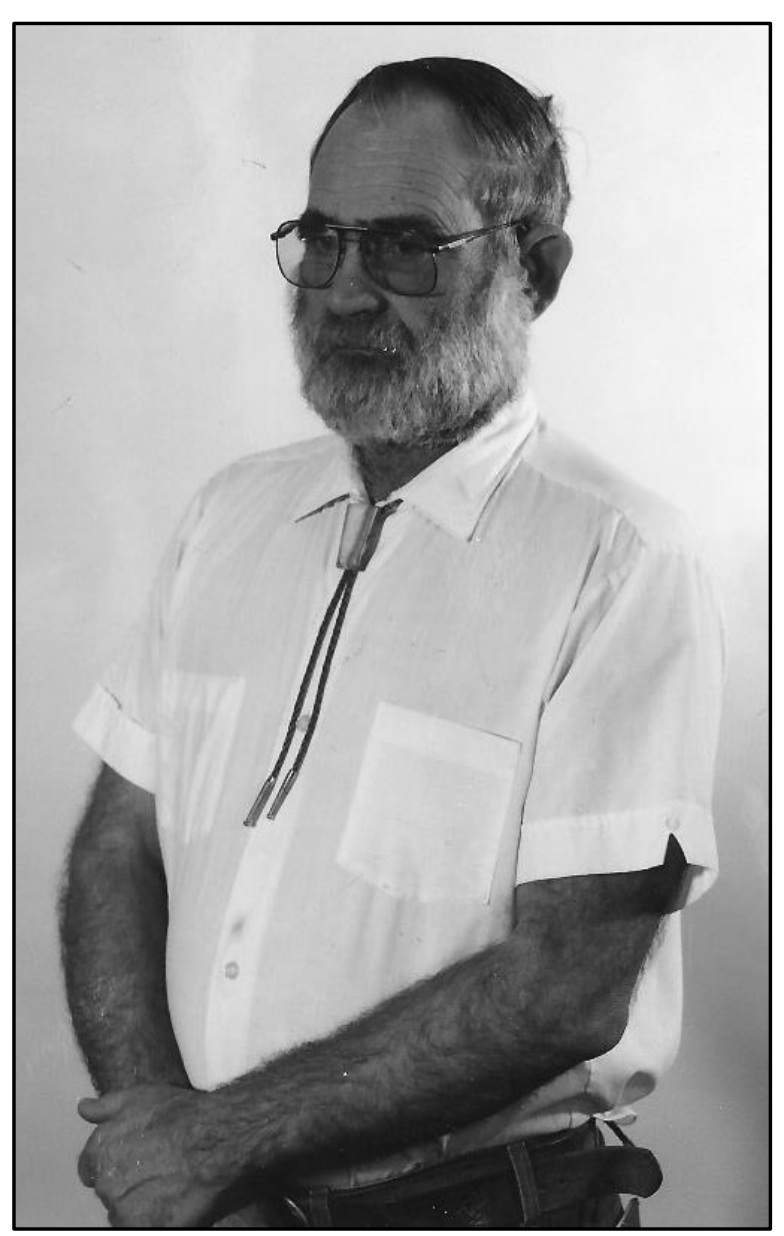

Figure 8. Billy Harrison, PPHM Curator of Archeology from 1969-1992, ca. 1985. Courtesy of Panhandle-Plains Historical Museum.

While there were a few early laws offering minimal protection to certain archeological and historic properties, such as the Antiquities Act of 1906, the Historic Sites Act of 1935, and the Reservoir Salvage Act of 1960, it was not until the passage of the National Historic Preservation Act (NHPA) of 1966 that historic preservation became a matter of national policy in the United States. This singular act legislating the preservation of archeological and historical sites created the institutions that govern cultural resource management today (King 1998:15). Among the provisions were the establishment of the National Register of Historic Places, a State Historic Preservation Officer (SHPO) for each state, and the requirement that all federal agencies must consider the impact of their plans and projects on historic properties through a process called Section 106 review.

Shortly after the passage of NHPA, individual states began passing complementary laws that mandated similar requirements for state lands. The Antiquities Code of Texas enacted in 1969 protects archeological and historic buildings on state property. In addition to establishing the designation of State Antiquities Landmark, this law "requires state agencies and other political subdivisions of the state, including cities, counties, river authorities, municipal utility districts, and school districts, to notify the Texas Historical Commission (THC) of ground-disturbing activity on public land and work affecting publicly owned historic buildings" (THC 2018). The THC is responsible for issuing antiquities permits for archeological studies or work at historic buildings and structures.

The Antiquities Code of Texas reshaped how and what archeological investigations were possible at PDCSP. TPWD operates under a Memorandum of Understanding (MOU) with the 
THC to conduct routine work at state parks under an annual permit and then report the work in an annual report. This MOU allows TPWD staff archeologists to conduct a specific level of work within the boundaries of the state parks. In accordance with the Antiquities Code, the MOU with the THC, and TPWD Environmental Policy, all ground-disturbing activities on state parks (and other TPWD properties) must be reviewed by the regional Cultural Resources Coordinator and, when necessary, the THC. The coordinator is then responsible for ensuring compliance, either by relying on personal expertise or contracting with another professional entity, such as a university or private contractor.

The earliest permit issued at PDCSP was in 1971 (TAC \#16) to Emerson L. Pearson. Pearson, a doctoral student at the University of Colorado at Boulder, was researching the soil characteristics at Palo Duro Canyon to better differentiate occupational from nonoccupational zones on a terrace above the canyon floor (Pearson 1974). He excavated three test pits at A704 (41RD66) and analyzed their soil chemistry and characteristics. Though this research used archeological deposits to better understand the canyon's geomorphology, it marks the first, and perhaps only, major testing of an archeological site at PDCSP employing modern-day, standard excavation methods.

\section{Rise of Cultural Resource Management and Permitted Projects: 1980s-2000s}

Cultural resource management projects at PDCSP took off in the 1980s, overshadowing any other type of archeological investigation. A consequence of NHPA and the Antiquities Code was that the emphasis for both federal and state agencies became preservation and management, rather than research. This new focus is reflected in the current mission of the TPWD, which is to manage and conserve the natural and cultural resources of Texas and to provide hunting, fishing and outdoor recreation opportunities for the use and enjoyment of present and future generations. To meet the requirement of managing cultural resources at PDCSP, TPWD staff archeologists have conducted various levels of archeological work within the boundaries of the state park since the mid-1970s. These include standard archeological fieldwork, as well as broader cultural resources management of historic structures, facilities, and landscapes. Table 1 provides a comprehensive list of these various survey, testing, and construction monitoring projects. 
Table 1 - Comprehensive List of Permitted Projects in PDCSP

\begin{tabular}{|c|c|c|c|c|c|}
\hline $\begin{array}{c}\text { TAC } \\
\text { Permit }\end{array}$ & $\begin{array}{l}\text { Publication } \\
\text { Year }\end{array}$ & $\begin{array}{c}\text { Date of } \\
\text { Investigation }\end{array}$ & Project Description & $\begin{array}{c}\text { Site } \\
\text { Trinomials }\end{array}$ & $\begin{array}{l}\text { Last Name } \\
\text { Investigator }\end{array}$ \\
\hline 16 & 1974 & $1971-1972$ & $\begin{array}{l}\text { Define/describe occupational zones in the } \\
\text { floor of PDC; only permitted excavation } \\
\text { within park }\end{array}$ & 41RD66 & Pearson \\
\hline 681 & 1988 & $\begin{array}{l}1 / 28 / 1988 \\
3 / 29 / 1988\end{array}$ & $\begin{array}{l}\text { Mesquite Removal - Site 41RD50 Survey } \\
\text { and Monitoring }\end{array}$ & $41 \mathrm{RD} 50$ & $\begin{array}{l}\text { Harrison and } \\
\text { Howse }\end{array}$ \\
\hline 779 & 1989 & $\begin{array}{l}\text { March \& } \\
\text { April } 1989\end{array}$ & Mesquite Removal, Survey and Monitoring & 41RD50 & $\begin{array}{l}\text { Harrison and } \\
\text { Howse }\end{array}$ \\
\hline 865 & 1991 & $10 / 15 / 1991$ & $\begin{array}{l}\text { Tree eradication at Mesquite Mesa, survey } \\
\text { and monitor }\end{array}$ & 41RD50 & $\begin{array}{l}\text { Harrison and } \\
\text { Howse }\end{array}$ \\
\hline 1209 & 1993 & $\begin{array}{l}\text { 1/27/1993; } \\
\text { 2/6/1993; } \\
3 / 08 / 1993\end{array}$ & RV Campground survey & & $\begin{array}{l}\text { Harrison and } \\
\text { Sansom }\end{array}$ \\
\hline 1217 & 1993 & Jan. 1993 & \multicolumn{2}{|c|}{$\begin{array}{l}\text { Waterline replacement in amphitheater area, less than one } \\
\text { acre in size }\end{array}$} & $\begin{array}{l}\text { Harrison and } \\
\text { Pace }\end{array}$ \\
\hline 1407 & 1994 & $5 / 19 / 1994$ & $\begin{array}{l}\text { Survey of proposed water line along 3.9-mile } \\
\text { corridor }\end{array}$ & $\begin{array}{l}\text { A347, } \\
\text { A105, } \\
\text { A148, A729 }\end{array}$ & $\begin{array}{l}\text { Harrison and } \\
\text { Pace }\end{array}$ \\
\hline 1407 & 1994 & $7 / 25 / 1994$ & \multicolumn{2}{|c|}{ Select locations for placement of temporary electric fences } & $\begin{array}{l}\text { Harrison and } \\
\text { Pace }\end{array}$ \\
\hline 128 & 1996 & $\begin{array}{l}\text { Nov. } 1976- \\
\text { Oct. } 1981\end{array}$ & $\begin{array}{l}\text { Inventory of cultural resources projects in } \\
\text { Texas State Parks 1976-1981 }\end{array}$ & Numerous & Ralph \\
\hline 297 & 1997 & $\begin{array}{l}\text { Nov. } 1981- \\
\text { Oct. } 1986\end{array}$ & $\begin{array}{l}\text { Inventory of cultural resources projects in } \\
\text { Texas State Parks } 1981-1986\end{array}$ & Numerous & Ralph \\
\hline 297 & 1997 & $8 / 01 / 1983$ & $\begin{array}{l}\text { Inspect new road into Cita Canyon, where } \\
\text { new site is identified (41AM9) }\end{array}$ & 41AM9 & Ralph \\
\hline 297 & 1997 & $4 / 04 / 1984$ & \multicolumn{2}{|c|}{ Assess proposed waste water line and new septic field } & Ralph \\
\hline 297 & 1997 & $7 / 25 / 1985$ & $\begin{array}{l}\text { Map and photograph pictographs in } \\
\text { rockshelter 41AM2 }\end{array}$ & $\begin{array}{l}\text { 41AM2, } \\
\text { 41AM6, } \\
\text { 41AM3 } \\
\text { A763 }\end{array}$ & Ralph \\
\hline 2111 & $\mathrm{~N} / \mathrm{A}$ & $\begin{array}{l}\text { May 1999- } \\
\text { April } 2008 \\
\text { (intermittent) }\end{array}$ & Cultural resource survey & 41RD79 & Shaller et al. \\
\hline 2111 & $\mathrm{~N} / \mathrm{A}$ & $\begin{array}{l}\text { April - Nov. } \\
2001\end{array}$ & Resurvey of previously recorded sites & various & Shaller et al. \\
\hline 2774 & 2003 & $\begin{array}{l}11 / 4- \\
08 / 2002\end{array}$ & $\begin{array}{l}\text { Metal detector survey of that portion of the } \\
1874 \text { Battle of Palo Duro Canyon that lies } \\
\text { within Palo Duro Canyon SP }\end{array}$ & 41AM13 & Cruse \\
\hline 4011 & 2007 & Sept. 2006 & $\begin{array}{l}\text { Pedestrian survey and subsurface testing of a } \\
0.2 \text {-acre tract to be impacted by the } \\
\text { installation of an air-quality sampling station }\end{array}$ & none & Hicks \\
\hline 4046 & $\mathrm{~N} / \mathrm{A}$ & Nov 2006 & $\begin{array}{l}\text { Metal detector survey of portions of the } 1874 \\
\text { Battle of Palo Duro Canyon (41AM1) }\end{array}$ & $\begin{array}{l}\text { 41AM1, } \\
\text { 41AM13 }\end{array}$ & Hicks \\
\hline 5707 & 2011 & $\begin{array}{l}\text { July - Nov. } \\
2010\end{array}$ & $\begin{array}{l}\text { Pedestrian survey of Fortress Cliff Ranch, } \\
\text { Parcel } 1\end{array}$ & & $\begin{array}{l}\text { Allday and } \\
\text { Tinsley }\end{array}$ \\
\hline 6159 & 2013 & $\begin{array}{l}\text { Mar. 31, } \\
\text { Dec. 8, } 2011\end{array}$ & $\begin{array}{l}\text { Pedestrian survey of new Rock Garden Trail } \\
\text { leading to newly acquired Fortress Cliff } \\
\text { Ranch }\end{array}$ & 41RD8 & Lyle \\
\hline 6159 & 2013 & $\begin{array}{l}\text { Mar. } 22-23 \& \\
\text { Dec. } 9,2011\end{array}$ & \multicolumn{2}{|c|}{$\begin{array}{l}\text { Pedestrian survey and limited testing ahead of project to } \\
\text { reconfigure Juniper Camp Loop to avoid flood-prone areas }\end{array}$} & Lyle \\
\hline 5755 & $\mathrm{~N} / \mathrm{A}$ & Sept. 2010 & Metal detector survey of Fortress Cliff Ranch & none & Lyle \\
\hline 6551 & 2013 & May 2013 & \multicolumn{2}{|c|}{$\begin{array}{l}\text { Intensive survey for bridge replacement, culverts, road } \\
\text { expansion }\end{array}$} & Ringstaff \\
\hline 7898 & 2018 & July 2017 & $\begin{array}{l}\text { Pedestrian survey and feature mapping of } \\
\text { CCC camp }\end{array}$ & 41RD79 & $\begin{array}{l}\text { Barnes and } \\
\text { Lyle }\end{array}$ \\
\hline
\end{tabular}


Annual reports for permits issued to TPWD for various archeological projects have been continuously produced since 1993 . However, the agency did not work under annual permits or produce annual reports before 1976 (see below) or from 1987-1993 when it worked under individually permitted projects. Prior to that, two inventories of cultural resources work were published to include reports for work on state park lands covered under 5-year permits issued by the Texas Antiquities Committee (TAC). The first of these permits issued, TAC \#128, covered the years 1976-1981 and authorized TPWD archeologist Ronald W. Ralph to survey all lands owned or under the agency's control. Background research, pedestrian survey, shovel testing, machine prospecting, and emergency collection were allowable, while general surface collection, site testing, and excavation were not, unless conducted under separate permits (Ralph 1996). No significant archeological work was conducted at Palo Duro Canyon State Park under TAC \#128, however numerous projects were conducted in nearby Caprock Canyons State Park in Briscoe County.

The following 5-year permit issued to TPWD, TAC \#297, encompassed work from 1981-1986. This blanket permit allowed TPWD archeologists to investigate state park lands "for the protection and preservation of many cultural resources while allowing the Department to move forward with development of plans in a timely and efficient manner. Recommendations offered to the Department included mitigation, full-scale excavations, testing and more intensive survey under separate permits to provide both baseline studies of cultural resources and to provide required clearance for construction" (Ralph 1997:1). Ralph served as the Principal Investigator under this permit and, with other TPWD and PPHM staff members, conducted archeological monitoring during prescribed burns (2/16/82), assessed grazing lease lands along Mesquite Mesa (5/23/83), assessed new access road routes into Cita Canyon (8/01/83), recorded site 41RD21 (10/05/83) near a corral and stock tank location, assessed proposed waste water facilities and septic field for the amphitheater (04/04/84), and re-inventoried archeological sites 41AM2, 41AM3 and 41AM6 (7/25/85) (Ralph 1997:179-184).

Ron Ralph was involved with PDCSP in different capacities throughout his career at TPWD. Raised in California and trained in field methods by State Archeologist Fritz Riddell and Peter Blue Cloud of the Mohawk Nation, Ralph joined TPWD in 1976 and served until his retirement in 1997. From 1976-1992, he was an archeologist in the Master Planning Branch of the State Parks Division, responsible for the inventory of cultural resources in new parks, capital improvement projects in existing parks, archeological project coordination, and monitoring of construction projects on park lands. He was also the liaison between TPWD and the Museum of Texas Tech University monitoring construction activities from 1986-1992 at the Lubbock Landmark, which was a TPWD property at that time. From 1992-1997, he served as the Resource Specialist for Region 2, covering a large part of Texas State Parks, including PDCSP. His responsibilities included inventory, assessment, stabilization, curation, and protection of both cultural and natural resources, and contributing to many park master plans. 
During the 1980s-1990s, Billy Harrison served as the Principal Investigator for several permitted compliance projects at PDCSP. These projects included monitoring mesquite removal near 41RD50 (TAC \#681; Harrison and Howse 1988), additional mesquite removal near 41RD50 (TAC \#779; Harrison and Howse 1989), and a two-acre survey with limited shovel testing prior to the construction of the Sagebrush RV campground (TAC \#1209; Harrison and Sansom 1993). Report co-authors Shirley Harrell Howse was the landowner of the nearby Lighthouse Canyon Ranch, while Dr. Andrew Sansom was the executive director of TPWD at the time.

Harrison also assisted TPWD with other projects including the review of a water line replacement in the amphitheater picnic area (TAC \#1217; Harrison and Pace 1993) and a survey of a proposed water line along a $3.9 \mathrm{~km}$ corridor through the bottom of the canyon (TAC \#1407; Harrison and Pace 1994). After Ron Ralph retired from TPWD in 1997, the agency went through a reorganization that included the addition of staff archeologists and other specialists in regional offices to oversee the resources of parks within major geographic regions of the state. Staff members from other TPWD programs including Lynn Pace, a biologist in the Resource Management Section, oversaw projects and contracts related to cultural resource management at PDCSP.

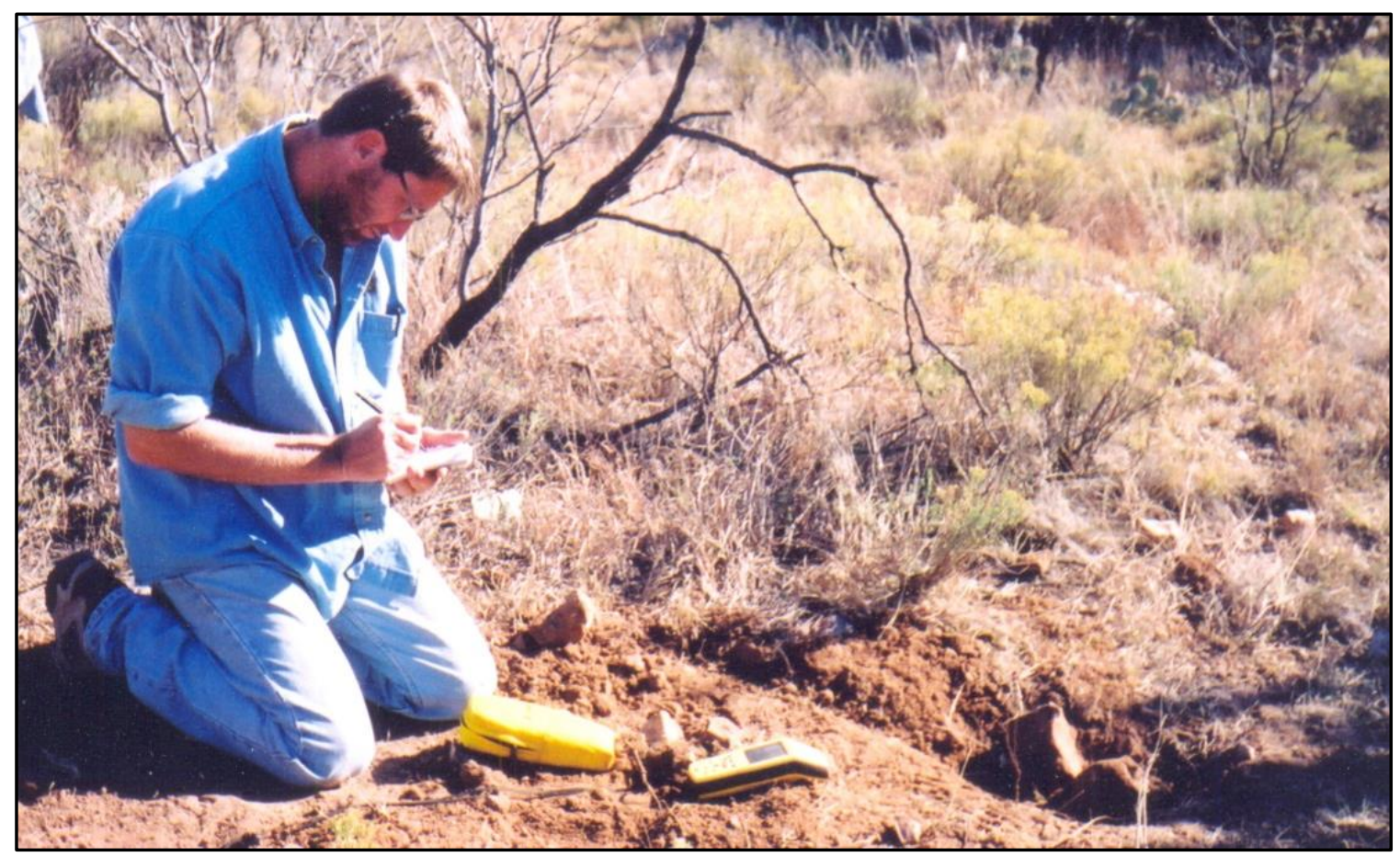

Figure 9. Kent Hicks, former TPWD Cultural Resources Coordinator, recording artifact locations with GPS at the Battle of Palo Duro Canyon site in 2002. Courtesy of Panhandle-Plains Historical Museum.

In 2000, Kent Hicks was hired as the Cultural Resources Coordinator (CRC) responsible for the management of the cultural resources at PDCSP and other parks within the Texas plains region. Hicks, originally from Bailey and Cochran counties in the western panhandle, had an educational background in environmental management (M.S., Texas Tech University). He applied 
a multidisciplinary approach to his archeological work, drawing from soil science, geomorphology, human geography, and ecology. Palo Duro Canyon proved the ideal environmental classroom for this approach to the study of past human behavior, particularly within this era of resource conservation and stewardship. Fieldwork at Palo Duro Canyon State Park included numerous small surveys for impact projects, assistance to PPHM staff with the park's site relocation and reevaluation survey, evaluations of the Canoncita and Harrell Ranch land acquisitions, and metal detection surveys of the Battle of Palo Duro Canyon and associated campsites.

TPWD records include project review files for over 30 small impact projects from 2000-2008 that Hicks managed (Figure 9). These range from septic system upgrades, trail repairs, landscaping and natural resources driven projects to historic CCC strutural repairs. In some cases, projects involving ground disturbances were monitored for inadvertant discoveries of archeological remains. These are filed as letter reports or within project review files, when no standard archeological work is conducted, nor any impacts or other cultural resources investigation triggers are involved. Additional archeology specific research projects were undertaken during this period, as well as routine maintenance involving historic cultural resources.

In the early 2000s, a series of Americans with Disabilities Act (ADA) compliance upgrades to historic buildings (mostly of CCC construction) were started. Additional upgrades, restoration, and repair work to deteriorating CCC-built infrastructure, including repairs to the Cow Camp cabins, CCC constructed trails, CCC rim cabins, and other features, were managed by teams of specialists that included the Cultural Resources Coordinator.

Two major projects transpired during the 1980s-2000s that contributed immensely to the archeological record of PDCSP. The first involved a resurvey of previously recorded sites, as well as a survey of the main CCC encampment (TAC \#2111). The second project was part of the THC's Red River War project and consisted of better defining the site limits of the well-known Battle of Palo Duro (TAC \#2744).

TAC \#2111 included two separate components: an evaluation of all known archeological sites in the PDCSP to document them with current data recording standards and to conduct an approximate 153-acre cultural resource survey of 41RD79, or the CCC camp occupied from 19331937. TPWD had originally contracted this work to Anna Jean (A.J.) Taylor, the archeologist on staff at PPHM from 1994-1997. However, Taylor left her position before the project began, and the contract was later renegotiated in 1999 with her successor, Dr. Jeff Indeck, assuming the role of Principal Investigator. Indeck had worked in cultural resource management for two decades before becoming Curator of Archeology at PPHM from 1997-2012. He had formal training in anthropology and paleontology from The Colorado College (B.A. 1978) and the University of Colorado at Boulder (M.A. 1982 and Ph.D. 1987). 
The pedestrian cultural survey of the main CCC camp or 41RD79 began on May 20, 1999 and continued on an occasional basis until its completion in April 2008. The survey design consisted of walking in 15-25 m transects across the project area recording, photographing, and measuring manmade features over 50 years of age (Shaller et al. 2013). Recorded features included cellars, rock walls, concrete slabs, road culverts, sidewalks, trash dumps, and building structures. Most were remnants of the CCC occupation. In April 2008, Indeck supervised and assisted with the recording of 78 shovel tests in the vicinity of $41 \mathrm{RD} 79$.

The portion of TAC \#2111 pertinent to the relocation and evaluation of previously recorded sites was completed from March 2000-October 2001. The objective of the survey was to identify the 41 sites recorded mostly by Hughes and Harrison decades earlier, re-record them using current data recording standards, and evaluate each for status as a State Antiquities Landmark in compliance with the Antiquities Code. This process involved several steps: collecting all extant records for each site, plotting their probable site locations, physically finding them, recording their locations with Global Positioning System (GPS), drawing site maps, describing condition and artifact density, collecting diagnostic artifacts, and excavating $50 \mathrm{~cm}$ square shovel tests to sterile soil at each site to determine the depth of cultural activity (Shaller et al. 2013). Finally, paperwork was submitted to obtain Texas State Trinomial numbers for each of the sites.

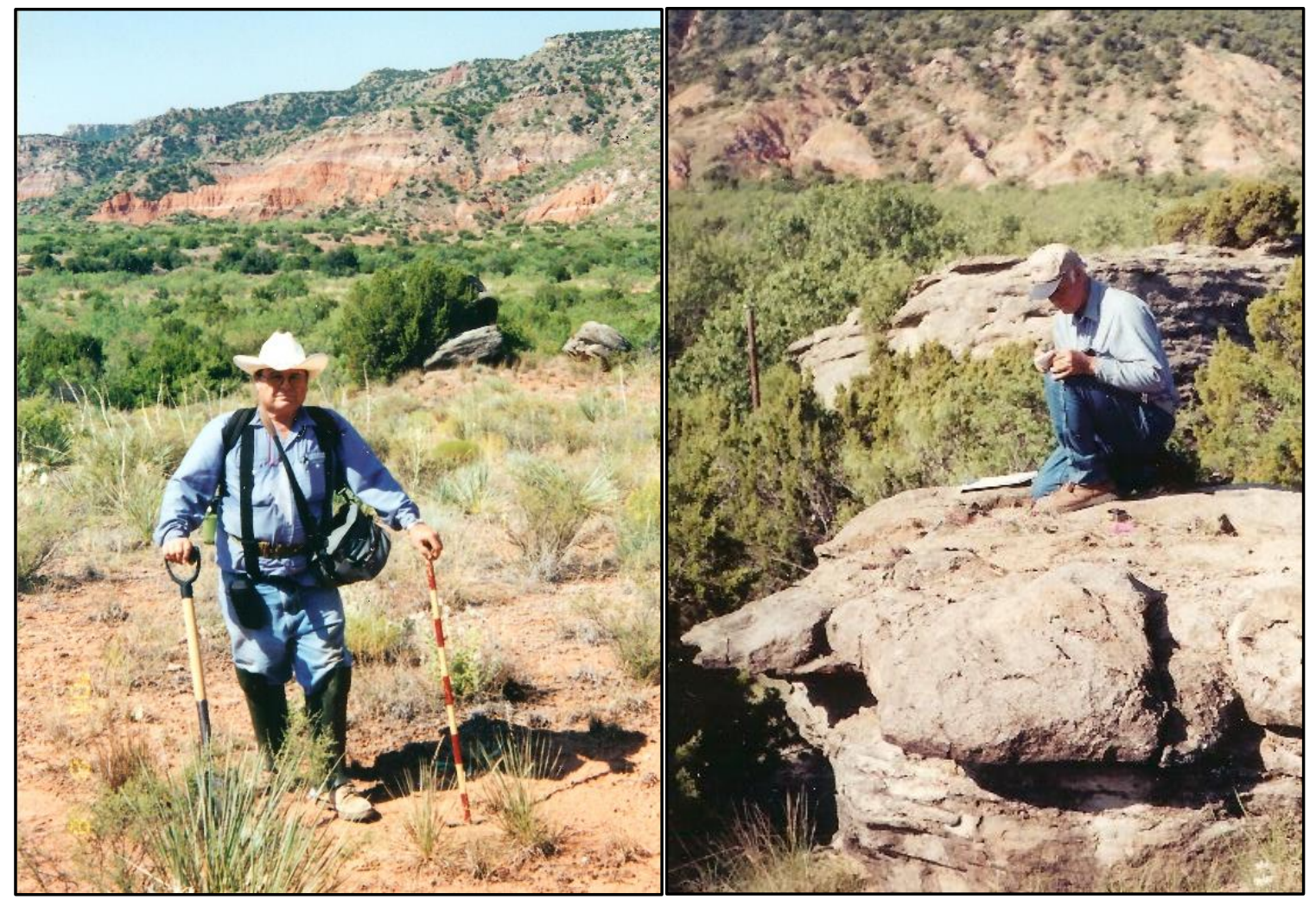

Figure 10. Rolla Shaller (I) and Alvin Lynn (r) working on the Palo Duro Resurvey project ca. 2001. Courtesy of Panhandle-Plains Historical Museum. 
Most of this resurvey was conducted by the Assistant Curator of Archeology at PPHM, Rolla H. Shaller, and third-party consultant, Alvin Lynn (Figure 10). Both had been students of Hughes. Shaller had grown up in Canadian, Texas, attending West Texas State (B.S. 1969) and worked at PPHM from 1969-1975 and then again from 1992-2008. Lynn was from the farming community of Whiteflat, Texas. He studied geology at West Texas State (B.S. 1961 and M.S. 1972) and had spent 31 years teaching high school science and social studies. Both had worked on several projects in the Texas Panhandle and had extensive knowledge of the archeology and geology of the region.

Opportunities for analyses of special archeological sites or collections have often been through partnerships. In May 2000, the Texas Rock Art Recording Task Force of the Texas Archeological Society formally documented the pictograph site (41AM2). Graphic drawings, photographs, forms, and other pertinent records are at the Texas Archeological Research Laboratory (TARL) in Austin. Another example of research collaboration involved a sample of pottery sherds from one of the sites located during the resurvey, the Water Crossing Site (41RD57), that was sent for further analysis. The artifact assemblage from that site included both Southern Plains and Southwest ceramic types. The objective of the analysis was to gain a better understanding of site function, identify the number of cultural occupations, and assign temporal affiliation (Wiseman 2005).

The second major project to transpire during the 1980s-2000s was part of the Red River War project. In 1998, the Texas Historical Commission undertook a broad archeological initiative to document sites from the Red River Indian Wars of 1874-1875 in the Texas Panhandle. Although the location of the site of the Battle of Palo Duro Canyon had been recorded in 1970 by Roberta Speer, the boundaries to this running battle site remained uncertain. In 2002, archeologists from TPWD and the THC partnered with multiple volunteers for a metal detector, pedestrian survey, and recording project to better define the portion of the 1874 Battle of Palo Duro Canyon that lies within PDCSP (TAC \#2744; Cruse and Hicks 2002).

Investigations conducted intermittently between 2001-2006 indicate that the site of the 1874 Battle of Palo Duro Canyon, originally recorded as a $300 \mathrm{~m}$ circle near the confluence of the Prairie Dog Town Fork of the Red River and Cita Creek, took a more linear shape up the canyon and side draws. Cartridge casings have been found as far as $500 \mathrm{~m}$ to the north and attest to the location of the running battle site, a locale of high significance to the cultural history of the canyon and subsequent state park. Work to complete reporting on this site is ongoing with a focus on preservation and interpretation (Hicks 2006; Lyle 2011). Factors to consider in the long-term stewardship of this site include the importance of the site, difficulty in navigating the terrain, the landscape-scale distribution of artifacts, and the delicate nature of preserving these resources on public land. 


\section{Park Expansion and the Impact-driven Projects: 2010 to the present}

Park attendance has increased significantly within the last decade. From 2012 to 2017, visitation increased $46 \%$. Within this six-year period, PDCSP has gone from the fifth highest visited Texas state park to the second. Several factors have contributed to such rapid growth in visitation, including less competition from other state parks that are either frequently at capacity or have been more heavily affected by recent natural disasters (i.e. extreme drought, flooding events, and hurricane damage), as well as garnering more attention nationally as a tourist destination. This rise in park visitation, in addition to the acquisition of several acres of adjacent lands in 2005 and 2008, has resulted in more impact-driven archeological projects.

Starting in 2008 and continuing through 2011, a series of construction projects were done that involved upgrades to existing historic buildings, modern campgrounds, and parking areas in the park. These projects all required archeological review and clearance to ensure that no cultural resources would be impacted. When Kent Hicks of TPWD transferred to the south coast region of Texas in 2008, Anthony Lyle became the current Cultural Resources Coordinator for the region that encompasses PDCSP. Lyle, born and raised in Pampa, Texas, grew up thinking that Palo Duro Canyon was the State Park of Texas, due to his many family outings there as a child. He

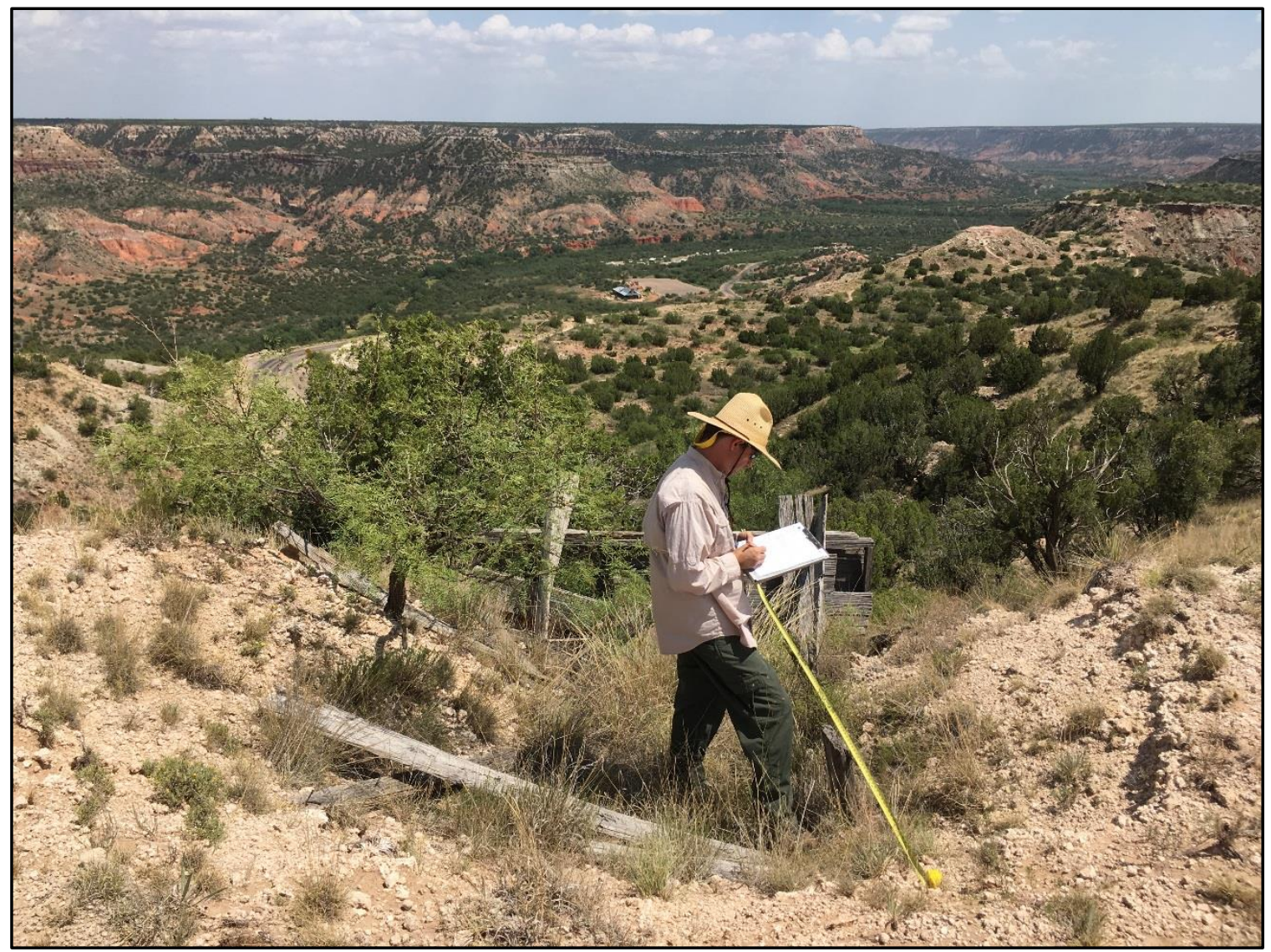

Figure 11. Tony Lyle, TPWD Cultural Resources Coordinator, recording a CCC feature at Palo Duro Canyon in 2017. Courtesy of Texas Parks and Wildlife Department. 
completed his degrees in anthropology at then Southwest Texas State University, or present-day Texas State University (B.A. 1993), and the University of Texas at San Antonio or UTSA (M.A. 2000). Before joining TPWD on the survey team in 2006, Lyle worked for UTSA's Center for Archeological Research on numerous and varied archeological projects across the state. These projects included working with colonial archeology at various Spanish missions, large scale surveys of public and federal lands, testing and mitigation projects, and testing of a $19^{\text {th }}$ Century U.S. Army encampment in west Texas (Figure 11).

Cultural resource reviews during this period included interior improvements to the CCC constructed buildings such as the gatehouse complex, Cow Camp, and Rim Cabins. In addition, the park continued to expand the trail system to meet user recreational needs. A consequence of greater park visitation is that trails are more highly impacted, especially in the rugged, erosional landscape of the canyon. Other significant park improvements included the first major campground expansion since the 1970s (Juniper Camping Loop) and the construction of a new group facility named the Mack Dick Pavilion for recreational use. These impact-driven projects required reviews for archeological site impacts.

As part of the planning and site preparation for the Mack Dick Pavilion, archeological investigations were undertaken that consisted of archival research into a former horse stables concession within the project area, a pedestrian survey of the approximate one-acre project area, and the placement of three backhoe trenches in the proposed septic field area to look for subsurface deposits. These investigations did not locate any archeological materials and subsequent monitoring of construction for cultural resources had similar results of no findings.

Road improvements also require archeological review. A project managed by Texas Department of Transportation (TxDOT) to address drainage issues on Park Road 5 consisted of erecting new and replacement culverts along the steep park road down into the main canyon. The culverts were installed through road cuts and, in some locations, required temporary removal and reinstallation of the CCC constructed rock "guard wall" along the road. TPWD Historic Sites and Cultural Resources Programs consulted with the THC on impacts to cultural resources along the park road. No archeological sites were impacted. Later in 2013, TxDOT conducted additional fieldwork in preparation for a major bridge project. The park's series of low water crossings on Park Road 5, which are hazardous during frequent flash flooding events, were replaced with bridges. The ensuing geomorphological analysis at the crossings along the Prairie Dog Town Fork of the Red River resulted in the determination that most of the fill was recent alluvium, and that there were no archeological sites within the areas of potential effects (TAC \#6551; Ringstaff 2013).

Additional field investigations in 2008 were contracted by a third party, Mid-Plains Rural Telephone Cooperative, along an existing easement through the park. Briscoe/Szarka Consulting Services conducted a 15-acre archeological survey for a fiber optic cable line and identified four prehistoric sites (41RD88, 41RD89, 41RD90, and 41RD91) and one historic site (41RD87). This 
survey went along the communications line corridor and easement that ran east across the entire width of the park, crossing the uplands near the entrance, down into Timber Creek draw, across the Prairie Dog Town Fork of the Red River, and beyond South Brushy Draw onto the Fortress Cliff property (Briscoe et al. 2008). Similarly, pedestrian survey, metal detecting, and shovel testing were employed in 2014 along a construction corridor of existing pipeline and a maintenance road in the Canoncita portion of the park within an existing oil and gas pipeline easement under a thirdparty contract (Cojeen and Briscoe 2014:1). The construction work was monitored, due to the proximity of three archeological sites (41AM1, 41AM7, and 41AM9). No cultural resources over 50 years of age were encountered in this survey or the subsequent construction monitoring project.

In 2011, TPWD contracted GeoMarine Incorporated (GMI) to conduct an intensive archeological survey of the Fortress Cliff Ranch, as part of a land acquisition that used federal grant funds. This survey was conducted on approximately 2,000 acres of upland terrain adjoining the east boundary of the main park and centered around a large drainage called the Tub Springs Draw (TAC \#5707; Allday and Tinsley 2011). In all, an additional 11 sites were recorded on the Fortress Cliff property acquisition (Allday and Tinsley 2011). As part of the land acquisition agreement discussed earlier in the chapter, a portion of that property was later sold by TPWD. These newly discovered archeological sites, now on private property, are monitored under the conditions set forth in a Conservation Easement between TPWD and the new landowner (Allday and Tinsley 2011; Hollingsworth 2008).

A metal detecting survey of the Fortress Cliff property was also initiated to supplement the contracted pedestrian survey by GMI. TPWD staff worked with volunteers on targeted metal detecting prospection of this area utilizing methods and techniques that had been developed for the previous surveys of the Battle of Palo Duro Canyon site. Evidence of early ranching camps and activities were recorded, including the concrete and stone spring box for which the name "Tub Springs" probably derives. The goals of the project were to establish a baseline survey of the newly acquired property and to document both historic metal artifacts and any potential evidence of the Native American routes utilized immediately after the initial Battle of Palo Duro Canyon in 1874 (TAC \#5755; Lyle 2011).

In 2011-2012, pedestrian surveys were conducted in advance of the development of a new hiking trail and upgrades to existing camping facilities. The proposed Rock Garden Trail was approximately $2.3 \mathrm{mi}$ in length and went from the rim above the "rock garden" down along a series of benches along the eastern slopes of the canyon. The study involved surveying the corridor along the proposed route for potential impacts. It resulted in revisiting one known archeological site (41RD8) and then rerouting the planned trail away from it to help with its long-term preservation (TAC \#6159; Lyle 2013a). No other cultural resources were encountered. Likewise, another archeological survey targeted the broad, flat setting of the floodplain. Upgrades and expansions to the Juniper Camping Loop required evaluation for potential impacts to cultural resources. This location has been flooded regularly and was subject to sheet erosion and fill from the western 
canyon rim. Evidence unearthed from a single backhoe trench showed a sequence of thin layers of silts and sands deposited rapidly over recent geologic time. These findings confirmed that the archeological potential in this zone was minimal (TAC \#6159; Lyle 2013b).

A new potential hazard to the archeological record became evident during this period. In 2012, TPWD staff began in earnest to identify areas known to contain cultural resources that were at risk from impacts by the growing "bouldering" or rock climbing activities taking place in the park. While these activities occur in PDCSP and at other state park and recreational areas, there are no designated bouldering or climbing areas within the park. One immediate concern was the possibility of damage to some of the known archeological sites under or near prominent boulders in areas such as the Rock Garden. This has resulted in continuing outreach to bouldering, mountain biking, and other recreational groups, with the goal of educating the public on the importance of the park's resources, lessening impacts to natural resources and cultural sites, and decreasing the amount of user defined trails. Limiting visitor impacts to existing trails is an ongoing challenge at state parks with fragile ecological zones such as those found at PDCSP. Additional projects such as adding new trailhead orientation panels and the installation of interpretive panels specific to cultural resources have sought to increase public awareness of the need to protect these fragile resources.

To meet increased visitor demands for more trails, a new multi-use trail was designed and planned in 2013. TPWD review staff reviewed an approximately $6.5 \mathrm{mi}$ long trail corridor. A standard archeological survey was done, and a conservation plan was devised to reestablish parts of a previously utilized, partially abandoned trail. Project planning was instrumental for routing the trail away from several known archeological sites. The trail contains sections originally constructed by the CCC and is thought to follow one of the original routes used by historic and prehistoric Native American groups. No archeological sites exist along the final trail corridor. The results of this work were included in a letter report on file at TPWD. A major contributor to the labor and expertise in design and construction of this and other trail projects is the Palo Duro Corps of Engineers (PDCE), a non-profit partner of TPWD and the state park. TPWD staff and PDCE have worked together since the 1980s in building and maintaining multi-use trails throughout the park.

Other small projects coordinated in the park since 2010 are the construction of a berm to prevent flooding in the Mesquite Campground restroom and septic fields, replacement of existing power line poles, a new access trail to the Dugout interpretive replica, the addition of a temporary fee booth at the Gatehouse entrance, the construction of a Mesonet weather station, repairs to the split rail fence near the scenic overlook, the placement of a commemorative bench along the CCC trail, the addition of an Equestrian Camp Ground, and the addition of two park host sites near the entrance to the Canoncita property. For these projects, resource clearances were obtained prior to ground disturbance to ensure the avoidance of impacts to any known cultural resources including archeological sites. 
As with any large public facility, routine maintenance projects are ongoing. Each require some level of archeological review. As of the publication date of this article, the most recent archeological investigation at PDCSP was an updated survey of the Civilian Conservation Corps (CCC) camp, site 41RD79, by TPWD staff archeologists (TAC \#7898; Barnes and Lyle 2018). The remains of the CCC camps, including concrete foundations, rubble piles, latrine pits, trash dumps and other features were recorded using hand-held GPS receivers capable of sub-meter accuracy. These results were mapped and overlaid with historic photographs within a Geographic Information System (GIS) to better visualize changes to this area of the park since the 1930s. This affords a level of data integration that is important when planning future park improvements such as utilities, new buildings, or roads. When coupled with historical research, it can also aid in planning interpretive components that help to educate the public regarding the history of the park and the importance of archeological stewardship. Recently, TPWD has acquired LiDAR (Light Detection and Ranging) imagery for use in planning future water system upgrades throughout the park. This type of highresolution spatial imagery rapidly collects voluminous amounts of $3 \mathrm{D}$ data, with vertical accuracy as high as $15 \mathrm{~cm}$, can aid in the detection of architectural features and other landscape modifications. Undoubtedly, archeologists and other researchers at PDCSP will soon incorporate LiDAR data in their studies and explorations of this immense outdoor laboratory.

\section{DISCUSSION AND CONCLUSIONS}

Since its establishment 85 years ago, archeological investigations at Palo Duro Canyon State Park have evolved significantly. These changes have occurred within a broader context of shifting park development and management priorities, from the earliest decades when the sustainability and future of the state park were so uncertain to the more recent park expansions acquired to meet high user demands. The historic preservation movement of the 1960s and the resulting legislative mandates gave rise to a new way of thinking about historic and archeological sites as cultural resources. Within the discipline, the creation and refinement of data collection and recording standards have significantly altered archeological practice. These methodological advancements, aided by seismic changes in technology, are clearly represented in the history of archeological investigations at PDCSP.

The earliest archeological efforts at the park involved discovering new sites and educating the public on the significance of artifacts to the history of the region. Even so, the prevailing view was that artifacts are relics of a past era, rather than material culture that collectively inform on the long history of human occupation in the canyon. Studer and others worked tirelessly to preserve the archeological record with the methods that were available to them. His system of recording sites on index cards and small-scale plat maps, while crude by today's standards, were valiant attempts to record a rapidly diminishing history. 
The arrival and permanence of Dr. Jack Hughes, a formally trained archeologist, in the area in the 1950s brought vast improvements in recording standards, field methods, and research design. His first accomplishment was to design a site numbering system that continues to be in use. He and his students then recorded more sites in the park and surrounding areas than has been recorded since. Site locations were plotted on the best maps available, initially on the costly, and still smallscale highway county maps and then on the USGS 7.5-minute series quadrangles. Although his site forms are meager, Hughes compensated by leaving field notes that were so descriptive and accurate that 50 years later, during the resurvey of PDCSP (TAC \#2111), all 41 documented sites were accurately relocated.

The approach to recording sites during the 1950s-1970s was highly exploratory. Sites were found randomly by people walking around looking for them and not as part of systematic surveys. However, the emphasis during this period was not merely discovering new sites. Hughes and his students were trying to better understand broader questions of site function, past settlement patterns, and cultural chronology. It is remarkable to consider that the bulk of what is known of the park's cultural resources derives from these informal "fieldtrips" and student projects that occurred from 1952-1976. The publication by Hughes (1978) on the archeology of Palo Duro Canyon, while relying heavily on archeological evidence found outside of park boundaries, remains the seminal work on what is known about this area's prehistory.

The passage of NHPA and then the Antiquities Code of Texas in the late 1960s altered both the focus of archeological investigations at PDCSP and how these studies were done. They required that each site now be evaluated in terms of its eligibility for inclusion in the National Register of Historic Properties and be subject to the Section 106 process. Thus, the emphasis from the late 1970s to the present has been on the preservation and management of cultural resources, rather than site discovery or new research. The rise of permitted projects at PDCSP in the 1980s2000s attests to these changes. The basis for defining a study area was, not by research potential, but by those areas that park development could potentially impact. Harrison, TPWD staff archeologists, and others from PPHM conducted various levels of archeological review for small surveys and construction monitoring projects.

The work conducted under Antiquities Permit \#2111 in the early 2000s marks a profound departure from traditional approaches to past work in the canyon. In terms of methods, the cultural resource survey of 41RD79 employed systematic surveying techniques, with transects walked at a consistent spacing. The number and intervals of shovel testing complied with survey guidelines adopted by the Texas Historical Commission. During the resurvey portion of the project, the locations of archeological sites were documented with GPS, ensuring locational accuracy to within $5 \mathrm{~m}$, compared to the $600 \mathrm{~m}$ previously offered by the USGS 7.5-minute quads. Site forms were filled out and submitted to TARL for inclusion in the statewide atlas of archeological sites. TARL assigned state trinomials to each of the A-sites to standardize site names at PDCSP with those from 
the rest of the state. This data is now readily accessible to qualified archeologists across the state and available for inclusion in future management or research-orientated projects.

The archeological work at the park from 2010 to the present has seen a refinement of archeological practices and an incorporation of new methods. Improvements in GPS has allowed site locational data to the sub-meter. LiDAR data acquired for the upper portion of the park between the entrance and the rim of the canyon has sub-centimeter spatial resolution. With adequate funding, mapping can be done much quicker and more accurately than is possible with hand-drawn maps. The incorporation of responsible metal detecting into the studies at PDCSP have allowed for targeted prospection of historical sites. This technology provides easier identification and better definition of sites that are of high significance to the recent history of the area.

Moreover, advances in photography, including the use of filters and digital image processing software, is aiding researchers in the potential to discover and record rock art imagery that is otherwise difficult to see. The use of UAVs (Unmanned Aerial Vehicles, or "drones") in archeological investigations has many promising, and proven, applications to the field in general and will offer current and future researchers at PDCSP easier access to different locales within the rugged terrain. One tentative future project could entail the use of a UAV to scan or digitally photograph all the individual boulders within the "Rock Garden" area of the park while simultaneously mapping the area. Such a project would enable a systematic visual survey of potential rock art imagery and other cultural features. This type of digital survey would greatly aid in efforts to better manage the cultural resources at Palo Duro Canyon State Park, contribute to the archeological record, and help protect these non-renewable resources.

In conclusion, this comprehensive review of the history of archeological investigations at Palo Duro Canyon State Park highlights how larger developments both within and from outside of the discipline have significantly influenced the amount and types of cultural resource studies that have occurred. It has endeavored to provide insights not on what is known about the history contained within this natural wonder, but how that knowledge was acquired and why. Two underlying threads emerge from this continuously evolving narrative. First, TPWD and PPHM have had a long and enduring partnership in the preservation and interpretation of these cultural resources. Perhaps, this relationship was inevitable. The establishment of the state park in 1933 coincided with the opening of the Panhandle-Plains Historical Museum. The local authorities in the archeology and geology of the region were, and continue to be, heavily invested in the future of both. Second, despite the number and variety of projects undertaken since the park's inception, surprisingly little is known about its prehistory. There is an abundance of evidence to indicate that the canyon was important to many different cultural groups at different times in the past 12,000 years. Yet, the archeology of PDCSP remains poorly understood and vastly under-researched. 


\section{REFERENCES CITED}

Allday, Sharlene and Clayton M. Tinsley

2011 Palo Duro Canyon State Park: Fortress Cliffs Ranch, Parcel 1, Intensive Archeological Survey, Randall and Armstrong Counties Texas. Geo-Marine, Inc. Miscellaneous Reports of Investigations No. 540, TAC Permit \#5707. Report on file, Texas Parks and Wildlife Department, Austin.

Amarillo Daily News [Amarillo, Texas]

1950 Premiere Day Arrives. 30 January:1. Amarillo, Texas.

Amarillo Sunday News and Globe [Amarillo, Texas]

1935 State Park Exhibit is Placed in Hotel Here. 13 January. Amarillo, Texas.

Barnes, Robin and Anthony Lyle

2018 Archeological Survey of Camp Palo Duro, the Civilian Conservation Corps Camp at Palo Duro Canyon State Park, Randall County, Texas. In Report of Archeological Investigations for 2017, edited by Richard B. Mahoney. Texas Parks and Wildlife Department, Cultural Resources Program, Austin.

Baugh, Timothy

1992 Protohistoric Cultural Manifestations on the Southern Plains: A Reconsideration of the Wheeler Phase and Garza Complex. In Cultural Encounters and Episodic Droughts: The Protohistoric Period on the Southern Plains, edited by Eileen Johnson, pp. 21-40. Lubbock Lake Landmark Quaternary Research Center Series 3, Museum of Texas Tech University, Lubbock, TX.

Beckcom, Christopher and Joelynn Barclay

2003 Palo Duro Canyon State Park Master Plan. Texas Parks and Wildlife Department, Infrastructure Division, Austin.

Bowers, Richard

2019 The Sad Monkey Railroad. Manuscript on file, Randall County Historical Commission, Canyon, Texas.

Boyd, Douglas K.

1997 Caprock Canyonlands Archaeology: A Synthesis of the Late Prehistory and History of Lake Alan Henry and the Texas Panhandle-Plains, Vol. II. Prewitt and Associate Reports of Investigations No. 110. Austin: Prewitt and Associates, Inc.

2004 The Palo Duro Complex. In The Prehistory of Texas, edited by Timothy K. Perttula, pp. 296-330. Texas A\&M University Press, College Station, Texas.

Bradly, Bill

n.d. Undated photograph of the Palo Duro Canyon Sky Ride. University of North Texas Libraries, The Portal to Texas History, crediting Deaf Smith County Library, https://texashistory.unt.edu/ark:/67531/metapth13838/, accessed May 6, 2019.

Briscoe, James, Nash Sherrod and Robert Walker 2008 Phase I Cultural Resources Inventory on the Mid-Plains Buried Fiber Optic Line Project in Palo Duro State Park, Randall County, Texas. Briscoe/Szarka Consulting Services. 
Submitted to Mid-Plains Rural Telephone Cooperative and N-Com, LLC, TAC Permit \#5062. Copies available from Texas Parks and Wildlife Department, Austin.

Cojeen, Christopher and James Briscoe

2014 Report on the Reconnaissance Archeological Investigations of the Enterprise Products Operating, LLC Proposed Anode Bed Project at Palo Duro Canyon State Park, Armstrong County, Texas. Cojeen Archeological Services, LLC, TAC Permit \#6772. Copies available from Texas Parks and Wildlife Department, Austin.

Cruse, Brett and Kent Hicks

2002 Palo Duro Canyon State Park: Randall and Armstrong Counties. Manuscript on file, Panhandle-Plains Historical Museum, Canyon, Texas.

Curry, W.H.

1950 Big Prizes are Offered for Coins at Palo Duro. The Crosbyton Review 29 June:3. Crosbyton, Texas. University of North Texas Libraries, The Portal to Texas History. https://texashistory.unt.edu/ark:/67531/metapth256403/, accessed April 23, 2019.

Deaf Smith County Historical Society

1982 The Land and Its People, 1876-1981: Deaf Smith County, Texas. University of North Texas Libraries, The Portal to Texas History. https://texashistory.unt.edu/ark:/67531/metapth16010/, accessed February 14, 2018.

Department of Interior State Park Emergency Conservation Work

1934 Palo Duro State Park - Texas. Topographic map enlarged from 1905 map by the Bureau of Forestry, U.S. Department of Agriculture, compiled and illustrated in 1934.

Foss, Kelly

1978 Finders Keepers: A Tale of Treasure in the Palo Duro Canyon. High Plains Living. October: 3-5.

Guffee, Eddie J.

1976 The Merrell-Taylor Village Site: An Archeological Investigation of Pre-Anglo, SpanishMexican Occupation on Quitaque Creek in Floyd County, Texas. Llano Estacado Museum, Wayland Baptist College, Plainview, Texas.

Gunnerson, James H.

1987 Archeology of the High Plains. USDA Forest Service, Denver.

Guy, Duane F.

2001 An Amphitheater for the Panhandle. In The Story of Palo Duro Canyon, edited by Duane F. Guy, pp. 179-193. Texas Tech University Press, Lubbock, Texas.

Habicht-Mauche, Judith

1988 An Analysis of Southwestern Style Ceramics from the Southern Plains in the Context of Plains-Pueblo Interaction. Ph.D. Dissertation, Harvard University, Cambridge. 
1991 Evidence of the manufacture of Southwestern-Style Culinary Ceramics on the Southern Plains. In Farmers, Hunters and Colonists: Interactions between the Southwest and Southern Plains, edited by Katherine Spielmann, pp 51-70. University of Arizona Press, Tucson.

Harrison, Billy R.

1991 Coins Drop from Sky in Fund-Raising Attempt. Amarillo Daily News 24 July:3. Amarillo, Texas.

Harrison, Billy R. and Shirley H. Howse

1988 Mesquite Removal - Site 41RD50: Survey and Monitoring, Randall County. TAC Permit \#681. Report on file, Panhandle-Plains Historical Museum, Canyon, Texas.

1989 41RD50 Mesquite Removal: Survey and Monitoring, Randall County. TAC Permit \#779. Report on file, Panhandle-Plains Historical Museum, Canyon, Texas.

Harrison, Billy R. and Lynn Pace

1993 Review of Water Line Replacement in the Amphitheater Picnic Area. In Texas Parks and Wildlife Department 1993 Annual Report, TAC \#1217. Copies available from Texas Parks and Wildlife Department, Austin.

1994 Cultural Resource Management: Water Line, Palo Duro State Park, Randall County, Texas. DAP Permit \#1407. Report on file, Panhandle-Plains Historical Museum, Canyon, Texas.

Harrison, Billy R. and Andrew Sansom

1993 RV Campground Survey: Palo Duro State Park, Randall County. TAC Permit \#1209. Report on file, Panhandle-Plains Historical Museum, Canyon, Texas.

Hicks, Kent

2001 Resource Management Plan for Palo Duro Canyon State Park. Manuscript on file, Texas Parks and Wildlife Department, Waco, Texas.

2006 Original field notes from the Battle of Palo Duro metal detecting survey. Notes on file, Texas Parks and Wildlife Department, Cultural Resources Program, Austin.

Hicks, Kent and Eileen Johnson

2000 Pastores Presence on the Southern High Plains of Texas. Historical Archeology 34(4):46-60.

Hicks, Kent and Anthony Lyle file, Texas

2013 Resource Management Plan for Palo Duro Canyon State Park. Manuscript on Parks and Wildlife Department, Waco, Texas.

Holliday, Vance T.

1997 Paleoindian Geoarcheology of the Southern High Plains. University of Texas Press, Austin. 
Hollingsworth, Ted

2008 Palo Duro Canyon State Park Proposed Addition Environmental Assessment for Land Acquisition. Land and Water Conservation Fund, National Park Service Compliance Document. Report on file, Texas Parks and Wildlife Department, Austin.

Hughes, David T.

1991 Investigations of the Buried City, Ochiltree County, Texas: With Emphasis on the Texas Archeological Society Field Schools of 1987 and 1988, Bulletin of the Texas Archeological Society, 60:107-148.

Hughes, David T. and Alicia Hughes-Jones

1987 The Courson Archeological Projects: Final 1985 and Preliminary 198.

Innovative Publishing, Perryton, Texas.

Hughes, Jack T.

1955 Little Sunday, An Archaic Site in the Texas Panhandle. Bulletin of the Texas Archeological Society, 26:55-74.

1978 Archeology of Palo Duro Canyon, Panhandle-Plains Historical Review, LI: 35-57.

1979 Archeology of Palo Duro Canyon. In The Story of Palo Duro Canyon, edited by Duane F. Guy, pp. 35-57. Panhandle Plains Historical Society, Canyon, Texas.

1991 Prehistoric Cultural Developments on the Texas High Plains. Bulletin of the Texas Archeological Society, 60:1-57.

2001 Archeology of Palo Duro Canyon. In The Story of Palo Duro Canyon, edited by Duane F. Guy, pp. 35-57. Texas Tech University Press, Lubbock, Texas.

Hughes, Jack T. and Charles Hood

1976 Archeological Testing in the Lakeview Watershed, Hall County, Texas. Archeological Research Laboratory, Killgore Research Center, West Texas State University, Canyon, Texas.

Jackson, Lisa Jeane

2013 The Imprint of the Civilian Conservation Corps on Palo Duro Canyon, 19331937. M.A. Thesis, West Texas A\&M University, Canyon, Texas.

Johnson, Eileen (editor)

1987 Lubbock Lake: Late Quaternary Studies on the Southern High Plains. Texas A\&M University Press, College Station.

Katz, Susanna R. and Paul R. Katz

1976 Archeological Investigations in Lower Tule Canyon, Briscoe County, Texas. Edited by James M. Malone and Kathy Freydenfeldt. Archeological Survey Report 16, Texas Historical Foundation, Austin.

King, Thomas F.

1998 Cultural Resource: Law and Practice, Altimira Press, Walnut Creek, CA. 
Knorpp, Kerry

2016 Guide to Palo Duro Canyon 1966 (forum), April 11, 2016.

https://texags.com/forums/39/topics/1905241, accessed May 6, 2019.

Lintz, Christopher

1986 Architecture and Community Variability of the Antelope Creek Phase in the Texas Panhandle. Oklahoma Archeological Survey, Studies in Oklahoma's Past No. 14, Norman, OK.

2002 The Radiocarbon Chronology of the Chalk Hollow Site 41RD51, a Stratified Lake Archaic-Woodland Site in the Texas Panhandle. Oklahoma Anthropological Society Bulletin 50(3) 14-46.

Lutz, Melanie and Willie Farmer

1968 Survey of a Mortar Hole Site in Palo Duro Canyon. Student paper at West Texas State University. Report on file, Panhandle-Plains Historical Museum, Canyon, Texas.

Lyle, Anthony

2011 Tub Springs Draw and Fortress Cliff Metal Detecting and Reconnaissance Survey, Palo Duro Canyon State Park, Randall and Armstrong Counties, Texas. Field notes and manuscript on file, Texas Parks and Wildlife Department, Cultural Resources Program, Austin.

2013a Rock Garden Trail Survey at Palo Duro Canyon State Park, Randall County, Texas. In Report of Archeological Investigations for 2012, edited by Richard B. Mahoney, pp. 121-129. Texas Parks and Wildlife Department, Austin.

2013b Archeological Survey and Testing for the Juniper Camping Loop Redevelopment at Palo Duro Canyon State Park, Randall County, Texas. In Report of Archeological Investigations for 2012, edited by Richard B. Mahoney, pp. 131-143. Texas Parks and Wildlife Department, Austin.

Malone, James M.

1970 Archeological Reconnaissance in the MacKenzie Reservoir Area of Tule Canyon. Archeological Survey Report 8, Texas Historical Survey Committee and the Texas Water Development Board, Austin.

Mallouf, Robert and R.D. Mandel

1997 Horace Rivers: A Late-Plainview Component in the Northeastern Texas Panhandle. Current Research in the Pleistocene 14:50-52.

Marcy, Ann

1972 Conversion of Canyon Lodge to Visit Center Moving Forward. Amarillo Daily News 30, June:31. Amarillo, Texas.

Mercado-Allinger, Patricia A.

2004 Archeological Reconnaissance at Caprock Canyons State Park. Briscoe County, Texas. TPWD. Austin.

Pearson, Emerson L.

1974 Soil Characteristics of an Archeological Deposit: Randall County, Texas. Bulletin of the Texas Archeological Society, 45:152-189. 
Perttula, Timothy K.

2004 An Introduction to Texas Prehistoric Archeology. In The Prehistory of Texas, edited by Timothy K. Perttula, pp. 5-14. Texas A\&M University Press, College Station, Texas.

Petersen, Peter L.

1978 A Park for the Panhandle: The Acquisition and Development of Palo Duro Canyon State Park. Panhandle-Plains Historical Review, LI: 145-178.

Quigg, J. Michael, Charles D. Frederick, Paul M. Matchen, and Kendra G. DuBois 2010 Landis Property: Data Recovery at Three Prehistoric Sites (41PT185, 41PT186, and 41PT245) in Potter County, Texas, Volume I. Submitted to Bureau of Land Management, TRC Report No. 150832. Copies available from TRC Environmental Corporation, Austin.

Ralph, Ronald W.

1996 An Inventory of Cultural Resources within the Texas Park System: November 1976 through October 1981. TAC Permit \#128. Texas Parks and Wildlife Department, Austin.

1997 An Inventory of Cultural Resources within the Texas Park System: November 1981 through October 1986. TAC Permit \#297. Texas Parks and Wildlife Department, Austin.

Rathjen, Frederick W.

2010 Studer, Floyd V. Handbook of Texas Online. Texas State Historical Association. Uploaded on June 15, 2010.

http://www.tshaonline.org/handbook/online/articles/fst84, accessed February 14, 2018.

Reed, Erik K.

1936 Special Report on Archeological Work at Palo Duro Canyon. Report on file, Panhandle-Plains Historical Museum, Canyon, Texas.

Ringstaff, Christopher

2013 Report for Intensive Archeological Survey, Bridge Replacement, Culvert Bypass, and New Roadway Construction. Report on file, Texas Parks and Wildlife Department, Cultural Resources Program, Waco, Texas.

Roberson, Wayne and J. David Ing

1973 Archeological Test Excavation at a Dugout in Palo Duro Canyon State Park. Report on file, Panhandle-Plains Historical Museum, Canyon, Texas.

Shafer, Harry J., John E. Dockall, Douglas Owsley, and Tom Ellzey

1991 The Canyon Creek Site (41 OC 13): A Component of the Southern Plains Equestrian Nomad Archeological Complex, Bulletin of the Texas Archeological Society, 62:285-334.

Shaller, Rolla H., Jeff Indeck, and Alvin Lynn

2013 Palo Duro Canyon State Park Archeological Site Revisit and Evaluation, Randall and Armstrong Counties, Texas. TAC Permit \#2111. Manuscript on file, Panhandle-Plains Historical Museum, Canyon, Texas. 
Speer, Roberta S. with Ginger Essary

1968 Report on Mortar Hole Site in Palo Duro State Park, Canyon, Texas. Student paper at West Texas State University. Report on file, Panhandle-Plains Historical Museum, Canyon, Texas.

Steen, Charlie R.

1981 The Life and Times of Erik Kellerman Reed. In Collected Papers in Honor of Erik Kellerman Reed, edited by Albert H. Schroeder, pp. 1-5. Papers of the Archeological Society of New Mexico 6, Albuquerque Archeological Society Press, Albuquerque.

Studer, Floyd V.

1931 Archeological Survey of the North Panhandle of Texas. Texas Archeological and Paleontological Society Bulletin, 3: 70-75.

1934 Hunting Indians in the Panhandle-Plains Museum. Panhandle-Plains Historical Review, VII: 79-94.

1939 The Palo Duro Canyon. Speech given to a local civic club. Manuscript on file, Panhandle-Plains Historical Museum, Canyon, Texas.

Taylor, A.J.

1984 New Mexican Pastores and Priests in the Texas Panhandle, 1876-1915, Panhandle-Plains Historical Review, LVI: 65-79.

Texas Historical Commission (THC)

2018 Antiquities Code of Texas of 1969. Electronic document, http://www.thc.texas.gov/project-review/antiquities-code-texas, accessed February 2, 2018.

The Canyon News [Canyon, Texas]

1951 Treasure Hunt Starts Saturday with Prizes Numbered Coins. 21 June:1. Canyon Texas.

1951 Third Treasure Hunt Gets Good Support. 31 May:1. Canyon, Texas.

The Claude News [Claude, Texas]

1949 Treasure Hunters to Head for Palo Duro Sat., May 28. 20, May:1-2. University of North Texas Libraries, The Portal to Texas History. https://texashistory.unt.edu/ark:/67531/metapth354094/, accessed April 23, 2019.

Tomka, Steve A.

2013 The Adoption of the Bow and Arrow: A Model Based on Experimental Performance Characteristics. American Antiquity 78(3): 553-569.

Tunnell, Gary

1962 Notes on the "Goodnight" Dugout. Student paper at West Texas State University. Report on file, Panhandle-Plains Historical Museum, Canyon, Texas. 
Upshaw, Emily Sorelle

1972 Palo Duro Rock Art: Indian Petroglyphs and Pictographs. M.A. Thesis, West Texas State University, Canyon, Texas.

Welch, Kevin

2012 New Pavilion To Be Unveiled in Palo Duro Canyon. Amarillo Globe News 8 April. https://www.amarillo.com/article/20120408/news/304089847, accessed May 6, 2019.

Willey, Patrick S., Billy R. Harrison, and Jack T. Hughes

1978 The Rex Rodgers Sites. In Archeology at Mackenzie Reservoir, edited by Robert S. Weddle, Kathy Freydenfeldt, and Curtis Tunnell, pp. 51-68. Archeological Survey Report 24. Texas Historical Commission, Austin.

Wiseman, Regge N.

2005 Pottery from the Water Crossing Site (41RD57), Randall County, Texas. Manuscript on file, Panhandle-Plains Historical Museum, Canyon, Texas. 